\title{
Przestępstwo publicznego propagowania faszystowskiego lub innego totalitarnego ustroju państwa (art. 256 k.k.). Analiza doktrynologiczna wybranych wypowiedzi piśmiennictwa i judykatury. Część szczególna II
}

Spośród wypowiedzi piśmiennictwa dotyczących przestępstwa propagowania totalitarnego ustroju państwa, powstałych w pierwszym okresie funkcjonowania Kodeksu karnego z 1997 roku, nie wspomnieliśmy jeszcze o pracy Mariana Flemminga i Witolda Kutzmanna, poświęconej przestępstwom przeciwko porządkowi publicznemu ${ }^{1}$. Zasadniczo możemy w niej odnaleźć wszystkie już wcześniej podniesione, budzące duże wątpliwości zagadnienia. Przede wszystkim przyjmuje się w niej pogląd o ciągłości istotowej występującej między art. 270 $\S 2$ Kodeksu karnego z 1969 roku (dalej: k.k. z 1969) a art. 256 k.k. Wprawdzie Flemming podniósł, że między oboma przepisami występują „znaczne różnice”, niemniej jednak poza jedną odmiennością — w postaci braku penalizacji w kodeksie z 1969 roku pochwalania innych systemów totalitarnych niż faszystowski - kolejnych różnic expressis verbis nie wyartykułował. Można ponadto domyślać się, że jako odmienność potraktowana została tu także zmiana czasownika określającego czynność sprawczą, gdyż słowa „pochwalanie” i „propagowanie” zostały wytłuszczone. Jednocześnie autor ten samo przestępstwo nazwał „propagowaniem faszyzmu i totalitaryzmu", a ponadto w tekście kilkakrotnie pisał o ,propagowaniu faszyzmu” (względnie, co było bliższe sensowi ustawy, o ,propagowaniu systemu faszystowskiego"). Przychylił się też do tezy Andrzeja Marka

${ }^{1}$ M. Flemming, W. Kutzmann, Przestępstwa przeciwko porządkowi publicznemu. Rozdziat XXXII Kodeksu karnego. Komentarz, Warszawa 1999. W ramach tej pozycji omówieniem interesującego nas tu przepisu art. 256 kk zajął się Marian Flemming. 
(o czym mowa będzie w kolejnym artykule cyklu), że „pochwalanie i propagowanie mogą być traktowane jako pojęcia bliskoznaczne". Te nawyki językowe wskazują na akceptację przez Flemminga przekonania, że pomimo wyraźnej różnicy w brzmieniu art. 270 § 2 k.k. z 1969 roku i art. 256 k.k. oba określone w nich przestępstwa są do siebie zbliżone i obejmują penalizację zachowań polegających na przekonywaniu „nieokreślonego, szerokiego kręgu odbiorców” nie tylko do systemu państwowego, lecz przede wszystkim do faszystowskiego lub innego totalitarnego światopoglądu ${ }^{2}$. O powodach, dla których takie podejście jest nietrafne, pisaliśmy już wcześniej ${ }^{3}$. Tu dodajmy zatem tylko, że w wypadku komentarza Flemminga przyjęcie perspektywy ciągłości budzi spore zaskoczenie, gdyż zdaniem tego autora - co sam zaznaczył w tekście — „pierwsza część dyspozycji art. 256 dotyczy totalitarnego systemu państwowego "4. Ta trafna intuicja (dosyć wyjątkowa w piśmiennictwie przedmiotu) nie została jednak niestety szerzej wykorzystana $\mathrm{w}$ dalszym $\mathrm{w}$ procesie komentowania.

Wśród innych nietrafnych tez zawartych w omawianej pracy warto odnotować stwierdzenie, że ,państwowe systemy antydemokratyczne zostały zdecydowanie odrzucone" w art. 13 Konstytucji RP ${ }^{5}$. Jak już widzieliśmy, tendencja do bezpodstawnego łączenia przywołanego przepisu polskiej ustawy zasadniczej z art. 256 k.k. była, osobliwie w początkowym okresie, dosyć powszechna i wynikała zapewne z posłużenia się przez prawodawcę $\mathrm{w}$ obu wypadkach słowami związanymi z faszyzmem i totalitaryzmem. Przypomnijmy tu zatem tylko dla porządku, że art. 13 Konstytucji dotyczy wyłącznie ograniczenia wolności stowarzyszania się (kreuje wyjątek w stosunku do praw gwarantowanych w art. 11, 12 oraz 58 i 59 Konstytucji RP) i nie ma bezpośredniego związku z wolnością słowa

${ }^{2}$ Za takim ujęciem zagadnienia przemawia również deklaracja Flemminga, że „przepis art. 256 stanowi, do pewnego stopnia, połączenie artykułów 270 § 2 i 272 KK z 1969 roku” —ibidem, s. 66 .

3 T. Scheffler, Przestęstwo publicznego propagowania faszystowskiego lub innego totalitarnego ustroju państwa (art. 256 k.k.). Analiza doktrynologiczna wybranych wypowiedzi piśmiennictwa i judykatury. Czesść ogólna, „Studia nad Autorytaryzmem i Totalitaryzmem” 34, 2012, nr 3, s. 97-117 (dalej: Przestępstwo art. 256 k.k. Czesść ogólna); idem, Przestęstwo publicznego propagowania faszystowskiego lub innego totalitarnego ustroju państwa (art. 256 k.k.). Analiza doktrynologiczna wybranych wypowiedzi piśmiennictwa i judykatury. Część szczególna I, „Studia nad Autorytaryzmem i Totalitaryzmem” 40, 2018, nr 4, s. 145-159 (dalej: Przestęstwo art. 256 k.k. Część szczególna I).

${ }^{4}$ M. Flemming, W. Kutzmann, op. cit., s. 61.

5 Inną, łagodniejszą wersją tego stanowiska jest teza, że art. 13 Konstytucji RP wprowadza zakaz totalitarnych systemów faszystowskiego, nazistowskiego i komunistycznego „w naszym demokratycznym państwie prawa” - S. Hoc, O przestępstwach z art. 256 K.K., „Problemy Prawa Karnego" 2003, nr 22, s. 55. Jest to mylące, ponieważ sam przywołany przepis Konstytucji takiego zakazu nie statuuje; jeżeli mielibyśmy pisać o zakazie takich systemów, to należałoby stwierdzić, że wynika on z całości regulacji ustrojowych odnoszących się zarówno do kwestii praw człowieka i obywatela, jak i do zagadnień struktury władz publicznych i ich relacji z obywatelami. 
i ekspresji (art. 54 Konstytucji RP) ${ }^{6}$, z którą próbuje łączyć z art. 256 k.k. Nie istnieje wobec tego żaden istotny prawnie związek normatywny między oboma przepisami, który w dodatku jakoś sankcjonowałby ograniczenia wolności wprowadzone w art. 256 in princ. k.k.

W przypadku przytoczonej wypowiedzi Flemminga zastanawiająca jest jednak jeszcze jedna zawarta w niej konstatacja, a mianowicie przyjęcie przez autora, że art. 13 Konstytucji odrzuca ,państwowe systemy antydemokratyczne”. Na potwierdzenie tego poglądu przytoczono w komentarzu in extenso rzeczony przepis, nie wyjaśniono jednak, jak miałoby to dowodzić tej kontrowersyjnej tezy. Regulacja ta bowiem nie „odrzuca” jakiegokolwiek „,systemu”, a jedynie zakazuje istnienia „partii politycznych i innych organizacji”, które w swoich programach (sic!) odwoływałyby się do „totalitarnych metod i praktyk działania nazizmu, faszyzmu i komunizmu". Warto zwrócić uwagę na to ograniczenie dotyczące programów, gdyż w dalszej części tego przepisu jest już mowa o zakazie istnienia organizacji, „których program lub działalność [sic!] zakłada lub dopuszcza [między innymi — T.S.] nienawiść rasową lub narodowościową" ". Nie o systemy antydemokratyczne w tym przepisie wobec tego chodzi, a o programy polityczne, które odwoływałyby się do „totalitarnych metod i praktyk”. To istotne, gdyż pomimo dużej niejasności samego sformułowania ${ }^{8}$ uchyla to możliwość delegalizacji organiza-

6 Por. M. Urbańczyk, Liberalna doktryna wolności słowa a swoboda wypowiedzi historycznej, Poznań 2009, s. 192.

7 Artykuł 13 Konstytucji zakazuje także istnienia partii i organizacji, „których program lub działalność zakłada lub dopuszcza” ponadto „stosowanie przemocy w celu zdobycia władzy lub wpływu na politykę państwa albo przewiduje utajnienie struktur lub członkostwa". Zob. szerzej L. Garlicki, Polskie prawo konstytucyjne. Zarys wykładu, Warszawa 2004, s. 67-69. Gwoli ścisłości zauważmy, że Garlicki nie w pełni zgodnie z brzmieniem art. 13 Konstytucji skatalogował podstawy zakazów istnienia partii i organizacji; zob. ibidem, s. 68. Warto też zwrócić tu uwagę, że konstrukcja omawianego przepisu Konstytucji zawiera - trudno orzec, na ile świadomie uczyniony — dosyć znamienny brak: wśród zakazanych partii i organizacji nie ma takich, których program lub działalność zakłada lub dopuszcza nienawiść, oprócz rasowej i narodowościowej, także religijną lub bezwyznaniową (antyreligijną).

8 Wbrew pozorom niełatwo wyjaśnić, jakie elementy „metod i praktyk” (w domyśle: politycznych) są swoiste wyłącznie dla totalitaryzmu, to jest - nie występują w wersjach nietotalitarnych. Na pierwsze wejrzenie chciałoby się rzecz, że chodzi w tym wypadku o ludobójstwo, zbrodnie przeciwko ludzkości, obozy zagłady lub obozy koncentracyjne, a także inwigilację społeczeństwa i rozbudowany aparat policyjny. Opis tych elementów ma już przebogatą literaturę (tu, przykładowo, można przywołać: E. Kolb, Die Maschinerie des Terrors. Zum Funktionieren des Unterdrückungs- und Verfolgungsapparates im NS-System, [w:] Nationalsozialistische Diktatur 1933-1945. Eine Bilanz, red. K.D. Bracher, M. Funke, H.A. Jacobsen, Bonn 1983, s. 270-284; K.D. Bracher, Die deutsche Diktaturoku Entstehung, Struktur, Folgen des Nationalsozialismus, Köln 1993, s. 370-401; N. Werth, Państwo przeciw społeczeństwu. Przemoc, represje i terror w Związku Sowieckim, [w:] S. Courtois et al., Czarna księga komunizmu. Zbrodnie, terror, prześladowania, Warszawa [b.r.w.], s. 57-253; Ph. Foro, Włochy faszystowskie, Kraków 2008, s. 73-110) i w tym zakresie można byłoby odtworzyć, czym są owe metody i praktyki. Niemniej jednak otwarte pozostaje pytanie, czy faktycznie są to elementy charakterystyczne wyłącznie dla totalitaryzmu. Zarówno obozy koncentracyjne i ludobójstwo, jak i zbrodnie wojenne czy praktyki służb specjal- 
cji czy partii, które będąc antydemokratyczne (w znaczeniu: przeciwne demoliberalizmowi, jako że do tego nurtu redukuje się współcześnie pojęcie demokracji), nie będą jednocześnie zakładały stosowania totalitarnych metod i praktyk ${ }^{9}$ (tak

nych sprzeczne z prawami człowieka mogą przecież wynikać z działań państwa liberalnego (wojna burska, Kongo pod panowaniem króla Belgii Leopolda I, eksterminacja Herero i Namaqua, naloty dywanowe, stosowanie napalmu czy praktyki stosowane w obozie w Guantanamo). Istnieje zatem możliwość, że zakaz istnienia partii i organizacji odwołujących się do totalitarnych metod i praktyk, o którym mowa w art. 13 Konstytucji RP, odnosi się nie tyle do kwestii swoistej, często nieludzkiej brutalności podejmowanej przez władze w ramach wymienionych tam systemów politycznych, ile raczej do samej istoty totalitaryzmu, polegającej na dążeniu rządzących do pozbawienia osób podmiotowości i do przejęcia pełnej, całkowitej kontroli nad ludzkim życiem. Mielibyśmy wówczas nawiązanie do próby wyjaśnienia, czym jest totalitaryzm, podjętej przez Giovanniego Sartoriego idem, Teoria demokracji, Warszawa 1994, s. 241-253. Przeciwko takiemu ujęciu przemawia jednak powołanie się przez twórców Konstytucji na historyczne, by rzec — „podręcznikowe”, przykłady systemów totalitarnych, które notabene wewnętrznie też są zróżnicowane z uwagi na różne poziomy totalitaryzacji życia w państwach „urzeczywistniających” wspomniane w art. 13 Konstytucji RP doktryny. Nie miejsce tu jednak na szersze zajęcie się tym zagadnieniem, które powinno stać się przedmiotem odrębnej, poważnej debaty naukowej. $\mathrm{Z}$ dotychczasowych publikacji zwracam uwagę na próbę rozwiązania związanego z tym dylematu, podjętą przez Michała Bartoszewicza w artykule Wokót problematyki art. 13 Konstytucji RP, „Państwo i Prawo” (dalej: PiP) 2005, nr 4, s. 36-48 (tu: s. 41-42), zgodnie z którą „Odwoływanie się do »metod i praktyk działania« nie powinno być rozumiane zbyt dosłownie jako nawiązywanie partii do konkretnych aktów władzy totalitarnej, lecz raczej akceptację [sic!] totalitarnego sposobu sprawowania władzy. Zagadnienie, o którą z doktryn totalitarnych chodzi w danym przypadku, wydaje się wtórne". Autor ten opowiedział się też za poglądem, zgodnie z którym cechą ideologii totalitarnych jest głoszenie potrzeby „,całkowitej kontroli społeczeństwa” lub opowiadanie się „,za rozwiązaniami idącymi w tym kierunku”. Można zatem przyjąć, że totalitarne „metody i praktyki działania” w ujęciu Bartoszewicza również należałoby rozpatrywać w kategoriach zaproponowanych przez Sartoriego. Niestety wywód ten nie został we wspomnianym artykule szerzej uargumentowany.

9 Przykładem tendencji do odchodzenia od liberalnego interpretowania przepisów Konstytucji RP także w dyskursie naukowym może być artykuł Agnieszki Bień-Kacały i Andrzeja Jackiewicza, Militant democracy - demokracja, która sama się broni (?), (PiP 2017, nr 8, s. 25-41), w którym na kanwie postanowienia Trybunału Konstytucyjnego z 6 kwietnia 2011 roku (sygn. akt Pp 1/10, OTK-A 3, 2001, poz. 27) przedstawiono następujący pogląd: „Trybunał umorzył postępowanie ze względu na niedopuszczalność wydania wyroku, wskazując, że program partii Narodowe Odrodzenie Polski nie odwoływał się wprost do totalitarnych metod działania, nie wyrażał nienawiści rasowej czy narodowościowej, a zatem kategorii wpisanych do art. 13 Konstytucji. Wątpliwości konstytucyjne wiązały się natomiast z symbolami, które partia chciała zarejestrować, a w których zakodowane były niedopuszczalne konstytucyjnie idee. Pomimo takiego podejścia Trybunał nie wydał jednak wyroku z powodu braków formalnych wniosku. Wydaje się jednak, że sprawa była ważna i dojrzała do interwencji pozytywnej Trybunału, a nie wyłącznie sądu rejestrowego, tym bardziej że sąd ten zarejestrował znaki niedopuszczalne konstytucyjnie. Ostatecznie jednak z uwagi na złożenie apelacji przez Rzecznika Praw Obywatelskich sąd apelacyjny uchylił postanowienie o ich rejestracji” - A. Bień-Kacała, A. Jackiewicz, op. cit., s. 36-37. Jak możemy przeczytać, przepis art. 13 Konstytucji RP został tu zinterpretowany jako podstawa stworzenia jakiejś nieznanej Konstytucji kategorii „niedopuszczalne konstytucyjnie idee”. Wspomniani autorzy poszli zresztą o krok dalej, gdyż uznali — krytykując orzeczenie niemieckiego Federalnego Trybunału Konstytucyjnego z 17 stycznia 2017 roku, odmawiającego delegalizacji partii NPD - że wyrok ten „może zatem stwarzać przestrzeń do rozwoju nieakceptowalnych w Europie ideologii” — ibidem, s. 37. Cytowa-

Studia nad Autorytaryzmem i Totalitaryzmem 41, nr 1, 2019

(C) for this edition by CNS 
będzie na przykład w odniesieniu do zdecydowanej większości organizacji anarchistycznych czy libertariańskich).

Także w odniesieniu do rozważań terminologicznych znajdujących się w komentarzu Flemminga możemy wskazać nieprawidłowości, o których pisaliśmy już na kanwie wcześniej omówionych tekstów innych autorów. Poza kwestiami wpadkowymi, takimi jak błędne przypisanie Benicie Mussoliniemu pierwszeństwa w użyciu pojęcia totalitaryzmu na określenie nowego systemu państwowego $^{10}$ czy bezpodstawne uznanie „frankizmu” za odmianę faszyzmu ${ }^{11}$, największe kontrowersje budzi podjęta tam próba ustalenia znaczenia pojęcia „totalitaryzm”. Aby móc dobrze zrozumieć i następnie opisać istotę problemu, musimy tu przywołać całą (skądinąd ciekawą) wypowiedź Flemminga:

Totalitarny ustrój państwowy charakteryzują, występujące łącznie: a) podporządkowanie życia politycznego i społecznego w państwie jednej ideologii, b) rządy jednej organizacji politycznej, np. partii o nieograniczonych kompetencjach, zanik demokratycznych form zarządzania, skrajny centralizm, c) kontrola rządzącej partii i podległych jej organów państwowych nad życiem społecznym, religijnym, nad opinią publiczną, ścisła cenzura prasy i innych mediów, uchylenie lub relatywizacja większości praw obywatelskich i praw człowieka, d) rozbudowa aparatu przemocy, zwłaszcza policji politycznej, zniesienie niezawisłości sądownictwa ${ }^{12}$.

ne wypowiedzi dobrze obrazują różnice między demokratycznym a liberalnym sposobem myślenia, co w konsekwencji prowadzi również do odmiennych sposobów interpretowania przepisów prawa. W sprawie wcześniejszych prób delegalizacji NPD zob. T. Scheffler, Ekstremizm polityczny: nieudana próba delegalizacji Narodowodemokratycznej Partii Niemiec (NPD) w latach 2001-2003 i jej znaczenie dla polskiego porzadku prawnego, „Studia nad Autorytaryzmem i Totalitaryzmem” 37, 2015, nr 3, s. 89-103.

10 Pierwszym, który określił wprowadzane po marszu na Rzym przez Mussoliniego reformy ustrojowe mianem systemu totalitarnego, był w 1923 roku przeciwnik faszyzmu Giovanni Amendola. W znaczeniu rzeczownikowym słowa „totalitaryzm” po raz pierwszy użył inny wróg faszyzmu - Lelio Basso. W obu wypadkach konotacje były wybitnie pejoratywne - S. Forti, Il totalitarismo, Roma-Bari 2001, s. 4-6. To, co uczynił Mussolini (a właściwie główny ideolog faszyzmu i jeden z najwybitniejszych neoheglistów XX wieku - Giovanni Gentile), to przejęcie tego słowa i nadanie mu ,pozytywnego" znaczenia poprzez wskazanie, że to, co w ustach antyfaszystów jest skazą, w ujęciu faszystów jest zaletą.

11 Krystyna Chojnicka, współautorka jednego z wiodących podręczników do doktryn politycznych i prawnych, zagadnienie to ujęła w następujący sposób: „Czasem mianem totalitarnych określane są systemy panujące w krajach takich, jak Hiszpania pod rządami generała Bahamonde Franco czy Portugalia za czasów Antonio de Oliveira Salazara. [...] Przymiotnik: totalitarny, faszystowski czy faszyzujący, pojawia się również w odniesieniu do wielu innych podmiotów, w tym także do państw Europy Środkowej; w opracowaniach z czasów PRL określa się w ten sposób rządy sanacji w Polsce po przewrocie majowym Piłsudskiego w 1926 roku. Jest to nieuprawnione stosowanie pojęcia »totalitaryzm « $\mathrm{i}$ »faszyzm « w sposób rozszerzony, co nie umożliwia precyzyjnej analizy konkretnych systemów. Znacznie właściwsze byłoby bowiem określenie ich mianem autorytarnych" - K. Chojnicka, H. Olszewski, Historia doktryn politycznych i prawnych. Podręcznik akademicki, Poznań 2004, s. 314.

12 M. Flemming, W. Kutzmann, op. cit., s. 62. 
Jak odnotowaliśmy, stanowisko to jest interesujące przede wszystkim dlatego, że jego autor, zamiast powtarzać dosyć bezproduktywnie — jak to zwykle miało miejsce - wypowiedzi zawarte w encyklopedii (najczęściej PWN), pokusił się o próbę skonstruowania własnej „definicji”. Na tym tle mogą się jednak pojawić dwie wątpliwości: po pierwsze, co do treści „definicji”, a po drugie, co do przydatności tworzenia takich definicji komentarzowych dla postępowań karnych. Odnośnie do podanego przez Flemminga wyjaśnienia, czym jest totalitaryzm, od razu pojawia się skojarzenie $\mathrm{z}$ omówioną przez nas wcześniej ${ }^{13}$ definicją stworzoną przez Carla Friedricha (i Zbigniewa Brzezińskiego) ${ }^{14}$. Jak widzimy, nastąpiło tu bowiem przejęcie czterech pierwszych znamion totalitaryzmu, o których pisał Friedrich, wraz z jego zastrzeżeniem, że winny one występować łącznie. Co jednak istotne, Flemming — bez wyjaśnienia przyczyn — wyeliminował z niej kwestię monopolu państwowego na środki przymusu oraz wprowadzoną dzięki Brzezińskiemu cechę odnoszącą się do biurokratycznej kontroli państwa nad życiem gospodarczym, a tym samym sam złamał postulowaną przez Friedricha (i Brzezińskiego) zasadę łącznego występowania wszystkich wymienionych w „definicji” cech do możności uznania jakiegoś systemu za totalitarny.

To spostrzeżenie prowadzi nas od razu do drugiej wątpliwości, a mianowicie do kwestii przydatności tworzenia takich „definicji” komentarzowych do postępowań karnych. Zwróćmy bowiem uwagę, że takie pojęcia, jak „totalitaryzm”, „faszyzm”, „komunizm” czy „narodowy socjalizm” (,nazizm”), są obecne w ustawie karnej nie tyle jako elementy języka potocznego, ile jako konstrukcje teoretyczne opracowane w ramach nauk społecznych do opisania pewnych zjawisk społecznych, politycznych i ustrojowych. Wprawdzie nie mają one powszechnie akceptowanych definicji (zresztą jak żadne inne pojęcie wykreowane w naukach społecznych), ale nie oznacza to, że takich (często rozbieżnych) prób przybliżenia znaczenia owych pojęć nie ma. Jeżeli zatem podczas orzekania sąd miałby ocenić, czy doszło do propagowania ustroju totalitarnego, to ustalając, co było przedmiotem propagowania, będzie musiał odwołać się do występujących w obrocie publicznym ustaleń nauk społecznych.

Odmienne w stosunku do poczynionych przez naukę ustalenia wyartykułowane w komentarzach (czy też w orzeczeniach, na przykład Sądu Najwyższego), nawet jeżeli byłyby atrakcyjne intelektualnie, nie będą mogły być podstawą wyrokowania, gdyż nie można racjonalnie zakładać, że sprawca znał tak ekskluzywne wypowiedzi doktryny lub judykatury. Próbując ustalać, czym jest ustrój faszystowski, czy komunistyczny, wyłącznie na podstawie komentarza lub uzasadnienia orzeczenia Sądu Najwyższego, skład orzekający naraża się w związku z tym także na konieczność czynienia dodatkowych ustaleń prowadzonych pod kątem wystąpienia przesłanki określonej w art. $28 \S 1$ k.k. (tudzież w pewnych okolicznościach

13 T. Scheffler, Przestęsstwo art. 256 k.k. Część ogólna, s. 100-101.

14 Zob. C.J. Friedrich, Z. Brzezinski, Merkmale der totalitären Diktatur, [w:] Nationalsozialistische Diktatur..., s. 225-236. 
w art. 30 k.k. $\left.{ }^{15}\right)^{16}$. W wypadku bowiem akceptacji rozszerzającej interpretacji art. 256 k.k. (to znaczy zakładającej, że penalizuje on także „propagowanie” idei) występujące w komentarzach i orzecznictwie różnego rodzaju odmienności w ustalaniu zakresu znaczeniowego pojęcia „totalitaryzm” (oraz związanych z nim pojęć, takich jak „faszyzm”, „narodowy socjalizm” — „nazizm”, czy „komunizm”) powinny skłaniać zarówno organy ścigania i sądy, jak i przedstawicieli nauki do refleksji nad możnością rozpatrywania czynów kwalifikowanych na podstawie tego przepisu w kontekście ewentualności wystąpienia chociażby błędu co do znamion czynu zabronionego (a może nawet, zgodnie z sugestią Zolla, jako błąd co do prawa). Przecież osoba oskarżona o popełnienie przestępstwa propagowania ustroju totalitarnego może zakładać, że do zaistnienia takiego ustroju konieczne jest zgodnie z podzielanym przez wielu ludzi nauki poglądem Friedricha i Brzezińskiego - łączne wystąpienie wszystkich sześciu wymienionych przez nich elementów i że w związku z tym propagowany przez nią pogląd niezawierający wszystkich postulowanych cech może być i jest podobny do koncepcji totalitarnej, ale jednak nie można go uznać za w rzeczywistości totalitarny. Skazywanie zaś za „propagowanie" ustroju podobnego do totalitarnego nie byłoby już nawet orzekaniem na podstawie wykładni rozszerzającej, tylko w oparciu o analogię.

Przedmiotem naszych dotychczasowych analiz doktrynologicznych ${ }^{17}$ były wypowiedzi przedstawicieli nauki powstałe tuż po wejściu w życie Kodeksu karnego z 1997 roku. Teraz do rozważań włączymy również działania orzecznicze sądów polskich. Jako pierwszą omówimy uchwałę Sądu Najwyższego z dnia 28 marca 2002 roku $^{18}$ z uwagi na to, że — jak zobaczymy w dalszej części artykułu — we względnie trwały sposób ukształtowała ona nietrafną interpretację analizowanego

15 Jak zauważył Andrzej Zoll, „błąd co do oceny prawnej czynu może polegać na przyjęciu wadliwej interpretacji przepisu i braku świadomości, że sądy stosują inną wykładnię. Przyjęcie wadliwej interpretacji może prowadzić do wniosku, że zakaz wynikający z normy sankcjonowanej nie odnosi się do określonego stanu faktycznego (tak trafnie SA w Katowicach w wyroku z dnia 29 listopada 2006 roku, II AKa 96/06, Krakowskie Zeszyty Sądowe 2007, z. 5, poz. 53)" — Kodeks karny. Cześśc ogólna, t. 1, cz. 1. Komentarz do art. 1-52, red. W. Wróbel, A. Zoll, LEX WK 2016, Komentarz do art. 30, uwaga 6.

16 Moglibyśmy tu bowiem mieć do czynienia z błędem, czyli ze zjawiskiem o podłożu psychologicznym polegającym na „niezgodności między rzeczywistością a jej odbiciem w świadomości człowieka”. Błąd taki na gruncie prawa karnego materialnego - jak wynika z przywołanych przepisów - może przybrać dwie postaci: error facti i error iuris. Szerzej zob. J. Giezek, Wina oraz okoliczności ja wyłączające, [w:] M. Bojarski, J. Giezek, Z. Sienkiewicz, Prawo karne materialne. Część ogólna i szczególna, Warszawa 2007, s. 170-189, tu: s. 170.

17 Szerzej na temat pojęcia i charakteru doktrynologii jako przedmiotu naukowego, a w szczególności jako płaszczyzny badawczej w naukach prawnych zob. M. Maciejewski, T. Scheffler, O doktrynologii: rozważania dotyczace przedmiotu oraz metody doktryn politycznych i prawnych, [w:] Myślenie o polityce i prawie. Przedmiot. Metoda. Praktyka, red. I. Barwicka-Tylek et al., Warszawa 2015, s. $295 \mathrm{n}$.

18 Uchwała SN z dnia 28 marca 2002 roku, sygn. akt I KZP 5/2002, „Orzecznictwo Sądów Polskich" (OSP) 46, 2002, nr 12, s. 647-648. Znajdujące się w artykule cytaty z uzasadnienia uchwały SN pochodzą z tej publikacji i oznaczane będą jako OSP 2002. 
przepisu. Orzeczenie to zapadło w efekcie pytania prawnego zadanego przez Sąd Okręgowy w O., sformułowanego na tle następującego stanu faktycznego. W dniu 1 lipca 2000 roku w miejscowości R. w klubie „U Hasana” zostało zorganizowane spotkanie grupy osób (około 200 uczestników), w trakcie którego - jak to zauważyły „osoby postronne” — znajdujący się na zewnątrz lokalu „młodzi ludzie [...] co jakiś czas podnosili w geście pozdrowienia prawą rękę i skandowali Sieg heil i Heil Hitler". Wewnątrz klubu natomiast na ścianach zawieszone były flagi ,z symbolami faszystowskimi”. Sprawa, którą rozpatrywał Sąd Okręgowy w O. (a następnie Sąd Najwyższy), dotyczyła dwóch osób, które zostały oskarżone o to, że ułatwili innym uczestnikom spotkania publiczne propagowanie ideologii faszystowskiej poprzez udostępnienie klubu „U Hasana” (którego jeden z oskarżonych był faktycznym najemcą, a drugi wynajął klub na tę konkretną imprezę), zapewnienie obsługi wskazanego lokalu, rozpowszechnienie informacji dotyczących czasu, miejsca i przedmiotu spotkania, oraz w przypadku jednego z nich (Roberta S.) ponadto o to, że ten chcąc, aby inne osoby propagowały ideologię faszystowską, swoim zachowaniem ułatwił im to poprzez zorganizowanie środka „przewozu w postaci dwóch autobusów Państwowej Komunikacji Samochodowej w O.”.

Wydawać by się mogło, że w przedstawionym stanie faktycznym elementem mogącym rodzić pewne wątpliwości prawne będzie kwestia, czy okrzyki Sieg heil lub Heil Hitler (związane bezpośrednio z narodowym socjalizmem) można sensownie przypisywać ideologii faszystowskiej albo też czy dopuszczalne prawnie jest formułowanie niezgodnego z brzmieniem przepisu ustawy zarzutu ,propagowania ideologii faszystowskiej”. Osobliwie ten ostatni problem powinien był się przecież niejako wprost narzucić składom orzekającym, czy to sądu okręgowego czy to Sądu Najwyższego, ze względu na prowadzone w obu wypadkach porównania brzmienia art. 270 § 2 k.k. z 1969 roku z art. 256 k.k.

Jak się jednak okazało, nie te zagadnienia zaprzątnęły uwagę Sądu Okręgowego w O. ani nawet nie rzeczywiście istotna przy egzegezie art. 256 k.k. kwestia znaczenia zwrotu ,propaguje faszystowski lub inny totalitarny ustrój”. Sąd Okręgowy zamiast tego skupił się bowiem (a za nim Sąd Najwyższy) wyłącznie na próbie ustalenia znaczenia samego wyrazu ,propagować” (w oderwaniu od „ustroju”). W uzasadnieniu postanowienia przedstawiającego Sądowi Najwyższemu właśnie to zagadnienie prawne do rozpatrzenia Sąd Okręgowy w O. błędnie podniósł, że użyte do określenia czynności sprawczej w art. 270 § 2 k.k. z 1969 roku sformułowanie ,pochwala" zastąpione zostało w art. 256 k.k. słowem „,propaguje”"19. Sąd ten (odwołując się do Stownika wspótczesnego języka polskiego i do jednego komentarzy do k.k.) zauważył przy tym, że czynność sprawcza polegająca na

19 Błąd polegał na tym, że pisząc o „zastąpieniu”, implicite przyjmuje się, że działanie polegające na pochwalaniu faszyzmu jest co najmniej zbliżone co do istoty do działania polegającego na propagowaniu totalitarnego ustroju państwa. Tym samym następuje pośrednie utożsamienie doktryny czy światopoglądu (świat myśli) z ustrojem państwa, czyli rzeczywistym układem sił i struktur w państwie (świat bytu). Szerzej zob. T. Scheffler, Przestępstwo art. 256 k.k. Część ogólna, s. 113. 
propagowaniu jest zakresowo szersza od czynności sprawczej polegającej na pochwalaniu, oraz wyraził w związku z tym ocenę, ,że jakkolwiek trudno wyobrazić sobie »propagowanie« czegoś bez wyrażenia pozytywnej oceny (pochwalenia) dla propagowanej treści, tym niemniej — jak się wydaje — aprobowanie czegoś czynności sprawczej »propaguje« nie spełnia". Warto odnotować, że Sąd Najwyższy, słusznie uznając trafność cytowanego spostrzeżenia, zdumiał się jednak,

że Sąd Okręgowy, napotykając na trudności w dokonaniu wykładni przepisu art. 256 k.k., ograniczył się do zapoznania się tylko ze stanowiskiem prezentowanym w jednym komentarzu, gdy piśmiennictwo na ten temat, choć nie odznacza się obfitością, to jednak jest znacznie bogatsze. Istotniejsze jest jednak, że właśnie zapoznanie się z literaturą przedmiotu prowadzi do wniosku, że na tle wykładni znamienia ustawowego „propaguje”, jakim posługuje się art. 256 k.k., wyłania się zagadnienie prawne wymagające zasadniczej wykładni ustawy, także w realiach procesowych sprawy rozpoznawanej przez Sąd Okręgowy w O. ${ }^{20}$

Pozwoliliśmy sobie na przytoczenie tego dłuższego fragmentu, gdyż dobrze obrazuje on wspomniane już proton pseudos egzegezy przestępstwa stypizowanego $\mathrm{w}$ art. 256 in princ. k.k., polegające na bezpodstawnie przyjmowanym założeniu (często implicite), że istnieje jakaś ciągłość merytoryczna czy istotowa między ustawowym zakazem pochwalania faszyzmu a ustawowym zakazem propagowania totalitarnego ustroju państwa. Zdaniem Sądu Najwyższego, jak się za chwilę przekonamy, podstawowy problem związany z wykładnią przepisu art. 256 k.k. faktycznie dotyczył bowiem sposobu rozumienia słowa „propagować” ze względu jednak nie wyłącznie na jego treść, lecz także z uwagi na jego odniesienie do pojęcia „pochwalać”. Tym samym Sąd Najwyższy wpisał się w pojawiającą się w pierwszych wypowiedziach doktryny (odnotowaną w poprzednich dwóch artykułach) ideę nawiązywania do art. $270 \S 2$ k.k. z 1969 roku jako do swoistego, rzeczywistego poprzednika przestępstwa stypizowanego $\mathrm{w}$ art. 256 in princ. k.k. ${ }^{21}$

Przyjęcie wspomnianego przedzałożenia zdeterminowało — jak niżej zobaczymy — skutki procesu interpretacyjnego podjętego przez Sąd Najwyższy. Przede wszystkim członkowie składu orzekającego (przewodniczący i sprawozdawca Lech Paprzycki oraz Henryk Gradzik i Jacek Sobczak) uznali za „oczywiste" sięgnięcie w pierwszej kolejności po wykładnię gramatyczną, dzięki której, odwołując się ,tylko do zwykłego wyczucia językowego, nawet bez potrzeby sięgania do profesjonalnych słowników", można ustalić,

że określenie „pochwala” w art. 270 § 2 k.k. z 1969 roku nie może mieć takiej samej treści jak określenie ,propaguje” użyte w art. 256 k.k. Nie budzi bowiem żadnej wątpliwości, że propagowanie może, ale nie musi być połączone z pochwalaniem. Można bowiem coś pu-

20 OSP 2002, s. 647.

21 W wydanym w 1997 roku Kodeksie karnym, zawierającym zestawienie tekstu kodeksu z 1997 roku z odpowiadającymi mu jednostkami redakcyjnymi kodeksu z 1969 roku, przy art. 256 k.k. umieszczono art. 270 § 2 k.k. z 1969 roku i art. 272 k.k. z 1969 roku — Kodeks karny, Warszawa 1997, s. 224. 
blicznie pochwalać bez zamiaru propagowania, jak i propagować, nie pochwalając tego, co się propaguje ${ }^{22}$.

Porównując dodatkowo brzmienie art. $255 \S 3 \mathrm{k} . \mathrm{k}$. (publiczne pochwalanie popełnienia przestępstwa) i odwołując się do idei racjonalnego prawodawcy (dla którego wspomniane ,wyczucie językowe” nie mogło być obce), sędziowie doszli do wniosku, że umieszczenie przez ustawodawcę w art. 256 k.k. określenia ,propaguje" nie było przypadkowe, lecz zmierzało do ukształtowania zakresu kryminalizacji zgodnie ze znaczeniem tego słowa ${ }^{23}$. W przekonaniu składu orzekającego zaś wyraz ten oznaczał w języku, ,polskim przede wszystkim upowszechnianie, szerzenie czegoś, w tym także poglądu, by do tego kogoś przekonać". W efekcie wspomniani sędziowie wyłożyli wstępny pogląd, zgodnie z którym wykładnia językowa miałaby ,prowadzić do wniosku, że propagowanie w rozumieniu art. 256 k.k. oznacza każde publiczne zachowanie, które stanowi upowszechnianie faszystowskiego lub innego totalitarnego ustroju państwa, podjęte w celu przekonania do niego"24. Stanowisko to poparli odwołaniem się do prób przybliżenia znaczenia słowa ,propagować” zawartych w dwóch słownikach języka polskiego oraz w jednym słowniku synonimów ${ }^{25}$.

Zanim przejdziemy do omówienia dalszej części uzasadnienia uchwały, osobliwie zaś do przedstawienia ostatecznego stanowiska zajętego przez Sąd Najwyższy w kwestii znaczenia pojęcia ,propagowanie” w rozumieniu art. 256 k.k., chcielibyśmy zwrócić uwagę na dwie kwestie, które pojawiają się na tle tego, co już zostało powiedziane. Pierwsza z nich dotyczy pewnej budzącej wątpliwość praktyki egzegetycznej polegającej na ustalaniu znaczenia słów znajdujących się w tekście ustawy za pomocą słowników. Na pierwsze wejrzenie może wydawać się to rozsądnym zabiegiem, gdyż rolą słowników językowych jest właśnie próba ustalenia znaczenia słów (związków frazeologicznych itp.) występujących w danym języku (najczęściej naturalnym), a w konsekwencji pomaganie użytkownikom danego języka w komunikacji za pomocą jednostek znaczeniowych w nim już występujących lub których stworzenie jest możliwe w jego systemie ${ }^{26}$. Przy

22 SN na potwierdzenie prawidłowości swego „wyczucia językowego” odnośnie do obu słów przywołał jednak pracę Praktyczny słownik współczesnej polszczyzny, red. H. Zgółkowa, t. 29, Poznań 2000, s. 217; Praktyczny słownik wspótczesnej polszczyzny, red. H. Zgółkowa, t. 32, Poznań 2001, s. 447.

23 W opinii SN, z którą się zgadzamy, nie można było zatem „podzielić w zasadzie odosobnionego poglądu, iż te dwa określenia znaczą to samo albo, że są to wyrazy bliskoznaczne". Tak: M. Flemming, W. Kutzmann, op. cit., s. 66, R. Góral, Kodeks karny. Praktyczny komentarz, Warszawa 2000, s. 336.

24 OSP 2002, s. 647.

25 SN odwołał się do następujących pozycji: Mały słownik języka polskiego, red. S. Skorupka, H. Auderska, Z. Łempicka, Warszawa 1968, s. 633; A. Dąbrówka, E. Geller, R. Turczyn, Stownik synonimów, Warszawa 1993, s. 102-103; Praktyczny stownik..., t. 32, s. 447.

26 Szerzej na temat podstawowych celów istnienia słowników językowych zob. A. Markowski, Stowo wstęne, [w:] Nowy stownik poprawnej polszczyzny, red. A. Markowski, Warszawa 1999, 
głębszym zastanowieniu pojawiają się jednak zastrzeżenia. Przede wszystkim warto zwrócić uwagę na to, że w ten zawoalowany sposób wprowadza się nową, pozaustawową podstawę orzekania ${ }^{27}$. $\mathrm{O}$ ile jest to dopuszczalne systemowo na gruncie prawa cywilnego czy szerzej - prywatnego (które tradycyjnie nie ogranicza podstaw rozstrzygania sporów do reguł stanowionych przez państwo), o tyle w sferze prawa karnego, rządzącego się co najmniej od czasów wielkich kodyfikacji liberalnych zasadą nullum crimen sine lege $e^{28}$, jest to mocno problematyczne ${ }^{29}$.

s. IX-XI. Osoby zainteresowane problematyką nauki o słownikach odsyłam do pracy Lexicography: Critical Concept, red. R.R.K. Hartmann, t. 1. Dictionaries, Compilers, Critics and Users, London-New York 2003.

27 Taka praktyka mogłaby wskazywać, że na poziomie praktyki orzeczniczej w Polsce pojmuje się prawo, wbrew powszechnym filopozytywistycznym poglądom, w kategoriach nie tyle pozytywistycznych, ile raczej opisanych w ramach doktryny realizmu prawniczego. Na temat realizmu prawniczego szerzej zob. J. Stelmach, R. Sarkowicz, Filozofia prawa XIX i XX wieku, Kraków 1998, s. 85-118. Bardziej szczegółowe informacje zob. S. Haack, O pragmatyzmie prawnym: dokąd wiedzie nas Ścieżka prawa?, [w:] Naturalizm prawniczy. Stanowiska, red. B. Brożek et al., Warszawa 2015, s. 131-164; M. Gorazda, U źródeł amerykańskiego realizmu prawnego, [w:] Naturalizm prawniczy..., s. 165-186; K. Eliasz, Obowiazywanie prawa w ujęciu skandynawskiego realizmu prawnego, [w:] Naturalizm prawniczy..., s. 187-200; M. Jakubiec, Tu-Tu Alfa Rossa a tezy skandynawskiego realizmu prawnego, [w:] Naturalizm prawniczy..., s. 201-220; J. Stanek, Rosyjski realizm prawny. Psychologiczna koncepcja prawa - powstanie i rozwój, [w:] Naturalizm prawni$c z y \ldots$, s. 221-232. Na marginesie można zauważyć, że rozpatrywanie prawa w Polsce w kategoriach realistycznych jest dopuszczalne na gruncie polskiej Konstytucji z uwagi na brzmienie art. 87.

28 Najczęściej sformułowanie brzmienia zasady nullum crimen sine lege przypisuje się niemieckiemu karniście Paulowi Johannowi Anselmowi von Feuerbachowi; zob. idem, Lehrbuch des gemeinen in Deutschland gültigen peinlichen Rechts, Giessen 1812, s. 22 (§ 20, III) - pierwsze wydanie książki datowane jest na rok 1801. Szerzej na ten temat zob. T. Scheffler, Zasada nullum crimen sine lege $w$ kontekście przestępstw stypizowanych $w$ art. art. 256 \& 1 k.k., „Opolskie Studia Administracyjno-Prawne" 16, 2018, nr 4 [w druku].

29 Gwoli ścisłości warto zaznaczyć, że w tradycji europejskiej można spotkać odstępstwa od ścisłego przestrzegania reguły nullum crimen sine lege nie tylko w systemach totalitarnych, lecz także w państwach odwołujących się do dziedzictwa oświeceniowego. W fundamentalnej pracy Chaïma Perelmana dotyczącej nowej retoryki możemy znaleźć następujące zestawienie dwóch odmiennych postaw orzeczniczych: „Art. $242 \mathrm{kk}$ niem. określa kradzież jako zabór cudzej rzeczy ruchomej w celu bezprawnego przywłaszczenia. Sąd Rzeszy dwukrotnie odmówił [...] uznania kradzieży energii elektrycznej za przestępstwo przewidziane w art. 242, opierając się na tym, że energia nie jest rzeczą. By więc nadać takiej kradzieży charakter czynu karalnego, Parlament niemiecki musiał uchwalić nowy przepis (art. 248). Co więcej, ponieważ określono w nim, że kradzież powinna nastąpić przy użyciu przewodu, Sąd Rzeszy odmówił poddania pod ten przepis kradzieży popełnionej w inny sposób (np. przez wrzucenie do automatu podrobionego żetonu). W 1935 roku [sic!]. Parlament musiał więc uchwalić drugi przepis (art. 265 kk niem.), który wprowadził karalność każdego niewłaściwego użycia aparatu automatycznego. Natomiast Sąd Najwyższy Holandii (Hoge Road) [sic!] nie wahał się uznać kradzieży energii elektrycznej za przestępstwo z art. $310 \mathrm{kk}$ hol., który mówi o zaborze rzeczy (goed) [...]. W drodze wykładni rozszerzającej [sic!] zrównano energię elektryczną z rzeczą, podczas gdy ustawodawca, który nie znał tego rodzaju kradzieży, z pewnością [sic!] nie brał jej pod uwagę w momencie uchwalania ustawy" - idem, Logika prawnicza. Nowa retoryka, Warszawa 1984, s. 96-97. Interesująca w tym kontekście może też być uwaga poczyniona przez Jerzego Wróblewskiego, odpowiedzialnego za wstęp i przypisy, komentującego 
Aby uniknąć nieporozumień, musimy zaznaczyć, że nie chodzi nam tu o to, że treści słowników zostają wymienione w tenorze wyroku (orzeczenia), lecz o to, że znajdujące się w nich wypowiedzi faktycznie decydują o treści wyroku (orzeczenia) poprzez ukierunkowanie i ukształtowanie sposobu rozumienia słów przez skład orzekający. Jednocześnie ów sposób rozumienia często nie jest przedmiotem sporu w toku postępowania sądowego, gdyż sąd nie informuje stron, że rozstrzygając, będzie posługiwał się danym słownikiem. Strony dowiadują się o tym zwykle dopiero z uzasadnienia wyroku, postanowienia czy uchwały. W wypadku możności zaskarżenia orzeczenia istnieje wprawdzie dla strony szansa podjęcia polemiki z takim ustaleniem (które — dopowiedzmy — nie ma charakteru ustalenia faktycznego, lecz jest ustaleniem prawnym, gdyż poprzez korzystanie ze słownika ustala się treść normy stosowanej w danym stanie faktycznym). Sama możność zaskarżenia orzeczenia kończącego postępowanie w danej instancji nie niweczy jednak nieprawidłowości takiej sytuacji. Powoduje ona bowiem i tak utratę możności wyłożenia poglądów w tej sprawie w danej instancji, a tym samym pozbawienie strony wpływu na treść orzeczenia. Zwróćmy ponadto uwagę, że w wypadku orzeczeń Sądu Najwyższego strona de facto zostaje w ten sposób całkowicie pozbawiona prawa do obrony, w szczególności z tego powodu, że nie wiedząc o wątpliwościach sądu dotyczących znaczenia danego pojęcia, nie mogła nawet podjąć jakiejkolwiek polemiki w tym zakresie ${ }^{30}$. A przecież nie tylko pomiędzy słownikami mogą istnieć rozbieżności co do określenia pól semantycznych poszczególnych pojęć, ale też same treści znajdujące się w słownikach podlegają niejednolitej interpretacji ${ }^{31}$. Co więcej, nie wolno w tym kontekście

w przypisie przytoczony fragment: „W polskim kodeksie karnym, który mówi o zagarnięciu »mienia« $[\ldots]$ zaliczenie energii elektrycznej do »mienia« nie nastręcza takich trudności" - ibidem, s. 97, dodatek w nawiasie kwadratowym do przyp. 16. Warto pamiętać, że komentarz Wróblewskiego datuje się na 1984 roku, a zatem powstał w dobie funkcjonowania reżimu komunistycznego.

30 Taki stan jest sprzeczny z zasadą rzetelnego i uczciwego procesu (fair trial), która zrodziła się w kulturach prawnych Zachodu na przełomie XVIII i XIX wieku i która zakłada konieczność umożliwienia w toku procesu upodmiotowienia jego stron. Jak zauważył polski filozof prawa Lech Morawski, „spektakularnym wyrazem” realizacji zasady fair trial „może być niemiecka klauzula konstytucyjna przyznająca prawo każdemu obywatelowi do bycia wysłuchanym przed sądem (Anspruch auf rechtliches Gehör), z której sądy niemieckie wyprowadziły zasadę, że podstawą do uchylenia wyroku może być sam fakt, że sąd nie wysłuchał lub nie ustosunkował się do argumentów jednej ze stron, nawet gdyby nie mogło to wpłynąć na wynik postępowania" — idem, Główne problemy wspótczesnej filozofii prawa. Prawo w toku przemian, Warszawa 2003, s. 216; szerzej w odniesieniu do fair trial zob. ibidem, s. 215-224. Także polska Konstytucja (art. 45 ust. 1) pozwala na wywiedzenie tezy o istnieniu w polskim porządku prawnym podobnej zasady.

$31 \mathrm{~W}$ odniesieniu do języka prawnego dziś już dominuje przekonanie, że „każda norma prawna podlega [...] wykładni (omnia sunt interpretanda) i nie istnieje, wbrew temu, co się sądzi, sfera zastosowania paremii clara non sunt interpretanda" - M. Safjan, Wyzwania dla państwa prawa, Warszawa-Kraków 2007, s. 77. Złagodzoną wersję tego poglądu wyłożył Zygmunt Ziembiński, w którego opinii ,paremia clara non sunt interpretanda ma w gruncie rzeczy taki sens, że przy językowej jednoznaczności przepisu nie ma podstaw, by odwoływać się do innych reguł niż reguły językowe. [...] Lepiej zresztą odwoływać się do paremii interpretatio cessat in claris (wykładnia 
zapominać, że normy językowe (zwłaszcza definicje i pseudodefinicje) wyartykułowane w słownikach nie mają waloru wiążącego dla użytkowników języka w takim sensie, w jakim wiążą normy prawne. Tym samym opieranie się na zawartych w nich treściach nadaje owym regułom mocy, której same z siebie owe normatywne wypowiedzi słownikowe nie mają. Warto też pamiętać, że pomimo dużych wysiłków badaczy konstruujących słowniki wyrażone w nich normy i znaczenia będą oddawały sposób myślenia i wysławiania się nie tyle całego społeczeństwa, ile przede wszystkim warstwy wykształconej. W ten sposób, odwołując się do rzekomo obiektywizującego i uniwersalnego źródła wiedzy, w rzeczywistości podczas orzekania sąd opierać się będzie na przekonaniach kreowanych przez wąską grupę specjalistów językowych. Taka praktyka również powinna stać się przedmiotem krytycznej refleksji, szczególnie w odniesieniu do sfery prawa karnego roszczącego sobie pretensję do bycia spadkobiercą tradycji oświeceniowo-liberalnej.

Można zapewne zbagatelizować zarzut wykorzystywania na gruncie prawa karnego pozaustawowej podstawy orzekania związanej z odwoływaniem się do norm językowych zawartych $w$ słownikach, przyjmując apriorycznie, że przedmiot potencjalnego sporu jest całkowicie wydumany lub nieistniejący (o czym mogłaby świadczyć dotychczasowa, niekwestionowana zasadniczo praktyka), albo odwołując się do bardziej wysublimowanych argumentów zaczerpniętych z filozofii prawa, osobliwie poprzez próbę wykorzystania którejś z koncepcji argumentacyjnych, na przykład retoryki prawniczej wspomnianego już Perelmana, konsensualnej teorii prawa Jürgena Habermasa albo teorii dyskursu prawniczego Roberta Alexy'ego.

O ile jednak takie podejście można byłoby jeszcze w jakiś sposób (chociażby za pomocą wspomnianych argumentów) usprawiedliwić lub wyjaśnić, o tyle za praktykę niedopuszczalną $\mathrm{w}$ toku wyrokowania $\mathrm{w}$ procesie karnym - i to jest kolejna kwestia, o której chcieliśmy wspomnieć przed powrotem do analizy treści uchwały - należy uznać zwyczaj specyficznego posługiwania się przez składy orzekające przy ustalaniu znaczeń pojęć ustawowych słownikami wyrazów bliskoznacznych. Specyfika ta polega bowiem na technice zakreślania pól znaczeniowych słów, którymi posłużył się ustawodawca, poprzez odwołanie się

kończy się po uzyskaniu jasnego rezultatu) niż clara non sunt interpretanda" - S. Wronkowska, Z. Ziembiński, Zarys teorii prawa, Poznań 2001, s. 165. Co jednak istotne, nie tylko język prawny, nie tylko język prawniczy, ale każdy język, aby mógł być językiem właśnie, z założenia musi charakteryzować się „pewnymi niedoskonałościami, takimi jak nieostrość, otwartość czy wieloznaczność, a w związku z tym nie można w nim uciec od interpretacji. Konieczność interpretowania — jak zauważył polski kognitywista i filozof prawa Bartosz Brożek — jest po prostu ceną, którą płacimy za to, że możemy się nawzajem porozumieć" — B. Brożek, Granice interpretacji, Kraków 2014, s. 146. Por. też przekonujący i erudycyjny wywód przeprowadzony przez Macieja Zielińskiego, Wyktadnia prawa. Zasady - reguly - wskazówki, Warszawa 2017, s. 53-57. 
do synonimów w szerokim znaczeniu ${ }^{32}$. Jest to praktyka sprzeczna z zasadą $n u l$ lum crimen sine lege, gdyż w ten sposób zamiast prawidłowego ustalenia zakresu czynu zakazanego przez ustawę sąd obejmuje penalizacją czyny podobne, ale nie tożsame z zakazanym. Stosowanie synonimiki ${ }^{33} \mathrm{w}$ prawie karnym jest bowiem równoznaczne $\mathrm{z}$ akceptacją stosowania wykładni rozszerzającej lub nawet analogii. Innymi słowy, korzystanie przez sądy karne ze słowników wyrazów bliskoznacznych byłoby do przyjęcia wyłącznie wówczas, gdyby składy orzekające za ich pomocą dążyły do stwierdzenia, jakie czyny nie zostały zakazane przez ustawodawcę, a nie - jak czyniły to dotychczas — do wskazywania za pomocą słów bliskoznacznych, jakie zachowania są rzekomo zakazane. Niebezpieczeństwo tworzenia $\mathrm{w}$ ten sposób per analogiam nieznanego ustawie czynu zabronionego notabene dobrze widać właśnie na przykładzie omawianej sprawy. Już bowiem na tym etapie Sąd Najwyższy poprzez zastąpienie słowa „propaguje” wyrazem ,upowszechnia” (a nie są to przecież pojęcia równoznaczne) przesunął uwagę odbiorcy w kierunku kwestii światopoglądowych i ułatwił w ten sposób przekonanie czytelnika/odbiorcy do swoistego zapomnienia, że czynność sprawcza polega na propagowaniu ustroju państwa, a nie propagowaniu wiedzy o takim ustroju lub jakiejś doktryny zakładającej stworzenie i funkcjonowanie państwa o określonym, uznanym za niedopuszczalny ustroju. To właśnie wykorzystanie synonimiki umożliwiło zatem Sądowi Najwyższemu przyjęcie istnienia rzekomej ciągłości co do istoty pomiędzy ustawowym zakazem pochwalania faszyzmu (art. $270 \S 2$ k.k. z 1969 roku) a ustawowym zakazem propagowania totalitarnego ustroju państwa (art. 256 in princ. k.k.).

Powróćmy jednak do omawiania treści uchwały. W celu intelektualnego usankcjonowania przyjętej ścieżki interpretacyjnej skład orzekający powołał się

32 Synonimy w pierwotnym znaczeniu oznaczały różne słowa mające jednakową treść (syn — wspólnie, razem; onymos — imię; wyraz). Jednak we współczesnej lingwistyce wyodrębnia się synonimy w wąskim znaczeniu (wyrazy równoznaczne) oraz synonimy w szerokim znaczeniu (wyrazy bliskoznaczne) - J. Lyons, Wstep do językoznawstwa, Warszawa 1975, s. 488-489. W polskim, starszym językoznawstwie przeważał wręcz pogląd, że synonimy to prawie wyłącznie wyrazy bliskoznaczne (por. „Synonim — wyraz bliski znaczeniowo innemu wyrazowi (czasem używany w znaczeniu wyrazu jednoznacznego) [...]. Wynika to z istoty synonimów jako wyrazów bliskoznacznych, lecz nie jednoznacznych, nadających się bardzo dobrze do interpretacji bogatej i zróżnicowanej rzeczywistości" - Stownik języka polskiego PWN, red. W. Doroszewski, t. 8, Warszawa 1966, s. 975.), jednak współcześnie przywraca się równowagę między znaczeniem szerokim i wąskim tego pojęcia (por. Synonim, [hasło w:] Nowy słownik, s. 997). Niemniej jednak pozostaje faktem, że - jak zauważył wybitny językoznawca Stephen Ullmann — czyste synonimy (synonimy w wąskim znaczeniu) są niezmiernie rzadkim zjawiskiem, gdyż język naturalny nie może pozwolić sobie na taki luksus - idem, The Principles of Semantics: A Linguistic Approach to Meaning, Oxford 1957, s. 109. Szerzej na ten temat zob. E. Grodziński, Językoznawcy i logicy o synonimach i synonimice, Wrocław 1985, s. 11-26.

33 Warto przypomnieć, że technikę synonimiki do dyskursu prawnego wprowadził sofista Prodikos z Keos - G. Reale, Historia filozofii starożytnej, t. 1. Od początków do Sokratesa, Lublin 2000, s. 271-272. 
na przedstawianą $\mathrm{w}$ piśmiennictwie przedmiotu jednolitą „,o do zasadniczych elementów” wykładnię. „Uważa się bowiem — podkreślił Sąd Najwyższy — że propagowanie, w rozumieniu przepisu art. 256 k.k., to s zerzeni e wi edzy o totalitarnym ustroju państwa i popieranie go, zachęcanie do wprowadzenia tego właśnie ustroju, podkreślanie jego zalet i przemilczanie wad [wyr. — T.S.]"34. Możemy w tej interesującej wypowiedzi zaobserwować, jak słowo „upowszechnianie”, które pojawiło się we wstępnym przybliżeniu znaczenia pojęcia „propagowanie”, pozwoliło na prawie niezauważalne rozszerzenie pola semantycznego ustawowego sformułowania mówiącego o „propagowaniu ustroju państwa”. Przypomnijmy bowiem, że ,upowszechnianie” zostało przez sędziów opisane jako „szerzenie czegoś, w tym także poglądu”; stąd już był tylko krok do akceptacji kontrowersyjnej tezy piśmiennictwa zakładającej, że upowszechnianiem ustroju jest nie tylko jego „szerzenie”, lecz także „szerzenie” poglądu tego ustroju dotyczącego. W konsekwencji Sąd Najwyższy mógł aprobująco przytoczyć wspomnianą wypowiedź Zbigniewa Ćwiąkalskiego, że propagowanie ustroju totalitarnego państwa to zarówno „popieranie go, zachęcanie do wprowadzenia tego właśnie ustroju" (czyli działania, które oddają literalną treść przepisu art. 256 in princ. k.k.), jak i „szerzenie wiedzy” o nim, a także „podkreślanie jego zalet i przemilczanie wad" (a zatem czyny, których karalność — w części dotyczącej pochwalania faszyzmu — przewidywał art. $270 \S 2$ k.k. z 1969 roku) ${ }^{35}$.

Warto zauważyć, że Sąd Najwyższy zdawał sobie najwyraźniej sprawę z tego, że poprzez treść podjętej uchwały w sposób jednoznaczny skierował interpretację art. 256 k.k. w stronę zakresu penalizacji wyznaczonej przez art. 270 $\S 2$ k.k. z 1969 roku, czyli w sferę wolności wyrażania poglądów. Świadczy o tym

34 Jak widzimy, SN zasadniczo zacytował tu komentarz pod redakcją Andrzeja Zolla, jednak faktycznie odwołał się do fragmentu opracowanego przez Zbigniewa Ćwiąkalskiego - Kodeks karny. Część szczególna. Komentarz do art. 117-277 Kodeksu karnego, red. A. Zoll, t. 2, Kraków 1999, s. 915. Skład orzekający powołał jednak w tym kontekście, na potwierdzenie ,jednolitości” poglądów, również inne pozycje, takie jak: komentarz Oktawii Górniok, [w:] O. Górniok, S. Hoc, S.M. Przyjemski, Kodeks karny. Komentarz, t. 3, Gdańsk 1999, s. 301; M. Flemming, W. Kutzmann, op. cit., s. 66; J. Wojciechowski, Kodeks karny. Komentarz. Orzecznictwo, Warszawa 2000, s. 487; R. Góral, op. cit., s. 336; A. Marek, Prawo karne, Warszawa 2001, s. 659; L. Gardocki, Prawo karne, Warszawa 2001, s. 287. Należy zgodzić się z tezą SN, że w żadnej z wymienionych wypowiedzi doktryny nie znalazło się wyraźne zakwestionowanie możności interpretowania art. 256 in princ. k.k. jako zakazu głoszenia poglądów. Jednocześnie jednak w żadnej z tych pozycji nie został przeprowadzony dowód na dopuszczalność takiej egzegezy. To milczenie doktryny, a w konsekwencji także SN, jest tym bardziej zadziwiające, że dotyka jednego z fundamentów klasycznego prawa karnego, czyli interpretowania przepisu wbrew zasadzie nullum crimen sine lege.

35 Omówienia wspomnianych w przyp. 33 wypowiedzi doktryny znajdują się w artykułach wymienionych w przypisie 3. Uwagi dotyczące poglądów Andrzeja Marka będzie można znaleźć w kolejnym artykule cyklu. 
zastosowanie zwrotu perswazyjnego (,Nie może przy tym budzić najmniejszych nawet wątpliwości”), wprowadzającego argument perswazyjny ${ }^{36}$,

że taki zakres kryminalizacji tego rodzaju zachowania nie stanowi, w świetle Konstytucji RP z 1997 (art. 31 ust. 3 w zw. z art. 54 ust. 1) i Europejskiej Konwencji Praw Człowieka z 1950 roku (art. 9, 10 i 17), nieuzasadnionego ograniczenia wolności wypowiedzi, o czym świadczy także konsekwentne stanowisko Trybunału Konstytucyjnego ${ }^{37}[\ldots]$ i Europejskiego Trybunału Praw Człowieka w Strasburgu ${ }^{38}$ [...]. Jest bowiem oczywiste (sic!), że demokratyczne państwo nie może tolerować i ma prawo penalizować m.in. propagowanie w zamiarze przekonywania do niego, każdego ustroju totalitarnego, a więc ustroju antydemokratycznego, w tym także ustroju faszystowskiego ${ }^{39}$.

Pomijając dyskusyjną tezę, że postanowienie zawarte w art. 31 ust. 3 Konstytucji RP może być podstawą ustawowego ograniczenia wolności wypowiedzi, potwierdzonego w art. 54 ust. 1 Konstytucji RP, główne nieporozumienie związane $\mathrm{z}$ argumentem podniesionym przez Sąd Najwyższy związane jest jednak $\mathrm{z}$ tym, że nie dotyczy on sytuacji wskazanej w art. $256 \mathrm{k}$.k. Unormowanie zawarte w tym przepisie nie odnosi się bowiem do propagowania poglądów, lecz do propagowania totalitarnego ustroju państwa, a relacja zachodząca między pojęciami „ustrój” a „doktryna” (lub „pogląd”, „koncepcja”, „myśl” itp.) nie kształtują się na zasadzie pochłaniania bądź tożsamości. W przypadku zaś podniesionego przez Sąd Najwyższy działania w postaci „szerzenia wiedzy” nie ma nawet możności racjonalnego dywagowania o przecinaniu się pojęć „Wiedza” i „ustrój”. Tym samym zakładanie, że art. 256 k.k. zakazuje propagowania ,wiedzy o ustroju totalitarnym", nie ma żadnego umocowania. Czyn w postaci upowszechniania wiedzy można byłoby zatem rozpatrywać co najwyżej albo jako pochwalanie popełnienia przestępstwa propagowania totalitarnego ustroju (art. $255 \S 3$ k.k. W zW. z art. 256

36 Szerzej w sprawie argumentacji perswazyjnej zob. M. Tokarz, Argumentacja i perswazja, „Filozofia Nauki” 10, 2002, nr 3-4, s. 11-15, 27-34. Por. też A. Klarman, Argumentacja perswazyjna jako technika społeczna $w$ polityce prawa, „Prakseologia” 2004, nr 144, s. 199-219, szczególnie s. 208-214.

37 Na poparcie tego poglądu SN przywołał dwie pozycje: J. Oniszczuk, Konstytucja Rzeczypospolitej Polskiej w orzecznictwie Trybunału Konstytucyjnego, Kraków 2000, s. 238 n.; oraz A. Frankiewicz, Regulacja wolności wypowiedzi w polskim porządku prawnym, [w:] Prawa $i$ wolności obywatelskie $w$ Konstytucji RP, red. B. Banaszak, A. Preisner, Warszawa 2002, s. 361 n. W tym ostatnim wypadku skład orzekający, przywołując rozważania zawarte na s. 393, wskazał, że zamieszczone tam ,,pewne” zastrzeżenia są „nieuzasadnione”. Trudno jednak w obliczu tak niejasnego stwierdzenia orzec, co SN miał na myśli.

38 W wypadku orzecznictwa ETPCz SN odwołał się do prac Marka Antoniego Nowickiego: Europejska Konwencja Praw Człowieka. Wybór orzecznictwa, Warszawa 1999 (w zakresie art. 9 $\mathrm{KE}$ - poz. 1271A, 1299, 1300, w zakresie art. $10 \mathrm{KE}$ - poz. 1319, 1324, 1330, 1338-1340, 1342B-1344, 1347, 1361D, 1374, 1404-1411, w zakresie art. 17 KE w zw. z art. 10 KE - poz. 1714-1719); Kamienie milowe. Orzecznictwo Europejskiego Trybunału Praw Człowieka, Warszawa 1996, s. 344-348, 382-388; Wokót Konwencji Europejskiej. Krótki komentarz do Europejskiej Konwencji Praw Człowieka, Kraków 2000, s. 302, 303.

39 OSP 2002, s. 648. 
k.k.), albo w kategorii przygotowania do propagowania ustroju, nigdy zaś jako jego propagowanie ${ }^{40}$. W tych okolicznościach podniesione przez Sąd Najwyższy zagadnienie dopuszczalności ograniczenia wolności wypowiedzi stałoby się istotne dopiero wówczas, gdyby ustawodawca przywrócił obowiązywanie przepisu art. $270 \S 2$ k.k. z 1969 roku albo uchwalił karnoprawny zakaz propagowania ideologii totalitarnej. Dopóki zaś prawodawca tego nie uczynił, dopóty ten fragment omawianego uzasadnienia uchwały Sądu Najwyższego nie tyle usprawiedliwia treść odpowiedzi na przedstawione przez Sąd Okręgowy zagadnienie prawne, ile raczej jest objawem nietrafnego odczytania zakresu penalizacji art. 256 k.k., wynikającego ze wspomnianego uznania (przynajmniej implicite) istnienia istotowej ciągłości pomiędzy art. 270 § 2 k.k. z 1969 roku a art. 256 k.k.

W celu złagodzenia dosyć drakońskich skutków, jakie pociąga za sobą zaproponowana wykładnia art. 256 in princ. k.k. dla konstytucyjnej wolności wyrażania poglądów, Sąd Najwyższy zdecydował się na wyznaczenie jakichś granic odpowiedzialności w tym obszarze. Przede wszystkim zaakceptował podniesioną przez Janusza Wojciechowskiego tezę, że nie stanowi propagowania w rozumieniu art. 256 k.k. samo prezentowanie zasad ustroju totalitarnego, w szczególności gdy takie działanie byłoby pozbawione zaangażowania się po stronie zakazanego systemu $^{41}$. Aby zaś doprecyzować, czym jest owo pozbawione angażowania się prezentowanie ustroju, skład orzekający odwołał się do stanowiska Lecha Gardockiego, w opinii którego takim dopuszczalnym propagowaniem ustroju byłoby cytowanie i publikowanie artykułów i książek autorów gloryfikujących lub propagujących ustrój totalitarny, jeżeli ich publikacja miałaby inne cele niż propagowanie takiego ustroju (szczególnie gdy byłaby połączona z krytycznym komentarzem) $)^{42}$, oraz do opinii Mariana Flemminga wyłączającej spod penalizacji sytuacje, kiedy prezentowanie takiego ustroju miałoby służyć wyłącznie manifestacji osobistych poglądów, a nie przekonywaniu do nich kogokolwiek ${ }^{43}$. Jak

40 Zdolność rozróżnienia faktów i wiedzy o faktach sięga co najmniej pracy Gorgiasza z Leontinoi, O naturze, czyli o niebycie, w której możemy przeczytać: „Tym bowiem, co przekazujemy, jest słowo, słowo zaś nie jest tym, co istnieje niezależnie od nas, ani bytem; nie przekazujemy zatem innym tego, co istnieje, lecz słowo, które jest czymś innym od tego, co istnieje niezależnie od nas. I jak zatem to, co widzialne, nie mogłoby się stać tym, co słyszalne, i na odwrót, tak też skoro byt jest tym, co istnieje niezależnie od nas, nie mógłby się stać naszym słowem" — J. Gajda, Sofiści, Warszawa 1989, s. 234. Por. też B.H.F. Taureck, Die Sophisten. Eine Einführung, Berlin 1994, s. 85-98.

41 J. Wojciechowski, op. cit., s. 487.

42 L. Gardocki, op. cit., s. 287.

${ }^{43}$ Flemming wskazał ponadto, że „dyspozycja art. 256 [...] nie obejmuje [...] teoretycznych opracowań dotyczących określonych kwestii, np. zakresu praw obywatelskich lub stosunków międzynarodowych" - M. Flemming, W. Kutzmann, op. cit., s. 66-67. Trudno stwierdzić, czego w rzeczywistości dotyczy cytowana uwaga. Możliwe, że Flemming chciał w ten sposób powiedzieć, że przepis art. 256 k.k. tworzy zakaz propagowania określonej totalitarnej doktryny wyłącznie pojmowanej jako całość. Tym samym niepodlegające penalizacji byłoby propagowanie poszczególnych składników takiej doktryny. Jeżeli rzeczywiście taka była intencja Flemminga, to główna kwestia 
widzimy, proponowane ograniczenia penalizacji sprowadzały się do próby wyłączenia z niej działań naukowych oraz możności swobodnej ekspresji własnych przekonań. W tym ostatnim wypadku realną wadą przedstawionego stanowiska było zastrzeżenie, że prezentowanie miałoby służyć „wyłącznie” manifestowaniu własnych poglądów bez przekonywania do nich innych osób. Przecież spełnienie tego wymogu w sytuacji działania publicznego jest praktycznie nieprawdopodobne, gdyż działając publicznie, co najmniej zakłada się, że przedstawiając innym własne przekonania, można przy okazji kogoś nakłonić do ich przyjęcia.

Przyjmując wskazane przesłanki, Sąd Najwyższy zdecydował się odpowiedzieć na szczegółowe pytanie Sądu Okręgowego w O.:

czy publiczne pochwalanie (sic!) faszystowskiego lub innego totalitarnego ustroju państwa, wyrażające się np. w wystawieniu na widok publiczny swastyki, wykonywanie gestów faszystowskiego pozdrowienia etc. tylko wtedy wyczerpuje znamiona określonego w art. 256 k.k. czynu zabronionego, gdy jednocześnie łączy się z publicznym upowszechnianiem (popularyzowaniem) wiedzy (sic!) o takim ustroju tj. uprawianiem propagandy (sic!).

Zwróćmy tu ponownie uwagę na charakterystyczne przekształcenie za pomocą synonimów treści art. 256 k.k. w duchu regulacji zawartej w art. $270 \S 2$ k.k. z 1969 roku: „pochwalanie”, ,upowszechnianie (popularyzowanie) wiedzy” i „uprawianie propagandy”. Znamienne jest, że Sąd Najwyższy nie tylko nie zakwestionował tego bezpodstawnego odstąpienia od literalnego brzmienia ustawy karnej, ale wręcz przejął ten sposób myślenia i zdecydował się na sformułowanie odpowiedzi na tak postawione pytanie. Wyjaśnił w związku z tym, że jak zostało to wcześniej rzekomo „wywiedzione”, wykładnia językowa miałaby prowadzić do następującego wniosku:

propagowanie oznacza prezentowanie tego rodzaju [to jest totalitarnego - T.S.] ustroju, co może mieć postać każdego zachowania, którego treścią jest rozpowszechnianie wiedzy dotyczącej ustroju państwa totalitarnego, a więc także wystawienie na widok publiczny symboli ta-

sporna na drodze do jej akceptacji będzie związana z relacją zachodzącą między częścią a całością: czy jeżeli przepis karny zakazuje propagowania całości doktryny, to czy tym samym zakazuje propagowania jej części? Prima facie mielibyśmy tu wprawdzie do czynienia z możnością zastosowania rozumowania z większego na mniejsze, niemniej jednak problematyczne jest to, czy całość doktryny można redukować do jej poszczególnych części i odwrotnie - czy do poszczególnych części doktryny, rozpatrywanych w oderwaniu od innych jej elementów oraz od niej jako całości, można z punktu widzenia prawa karnego podchodzić z takim samym rygorem? Innymi słowy: czy można odwoływać się do synekdochy w toku procesu egzegetycznego w prawie karnym bez narażenia się na zarzut działania wbrew zasadzie nullum crimen sine lege? Dla przykładu: jeżeli ktoś domaga się ustanowienia prawnego obowiązku uprawiania sportu przez młodzież, to czy propagowanie takiej koncepcji winno spotkać się z reakcją prawnokarną na podstawie art. 256 k.k.? Albo propagowanie koncepcji zakładającej, że_,działalność jednostek nie może wykraczać przeciwko interesom ogółu, lecz musi mieścić się w jego ramach i wszystkim przynosić pożytek" powinno być traktowane jak przestępstwo? Oba przypadki są fragmentami programu NSDAP z 1920 roku. Szerzej zob. M. Maciejewski, Od piwiarnianego klubu do organizacji wywrotowej. Nazizm w latach 1919-1924, Toruń 2005, s. 236, 241. 
kiego państwa, czy też wykonywanie określonych gestów identyfikowanych z takim ustrojem. Wszystko jednak zależy od [tego] [...], czy określone zachowanie stanowi publiczne prezentowanie tego ustroju i to podjęte z zamiarem bezpośrednim przekonywania do tego ustroju ${ }^{44}$.

To, co najbardziej zastanawia w wywodzie Sądu Najwyższego, to całkowity brak śladów podjęcia refleksji prawnej nad możliwością innej, oderwanej od tradycji narosłej wokół kodeksu z 1969 roku interpretacji art. 256 k.k. Trudno orzec, co było przyczyną tego swoistego zaniechania.

Powiedziawszy to, co zostało zrelacjonowane, Sąd Najwyższy powiedział już właściwie wszystko, aby przedstawić finalną tezę: ,propagowanie, w rozumieniu art. 256 k.k., oznacza każde zachowanie, polegające na publicznym prezentowaniu, z zamiarem przekonania do niego, faszystowskiego lub innego totalitarnego ustroju państwa". Jak widzimy, podstawowa $\mathrm{i}$ - jak się nam wydaje — jedyna istotna różnica $\mathrm{w}$ stosunku do pierwszego przybliżenia znaczenia słowa „propagowanie” sprowadziła się do zastąpienia pojęcia wyjaśniającego „upowszechnianie” przez wyraz ,prezentowanie”. Są to słowa bliskoznaczne, niemniej jednak różniące się znaczeniowo. Upowszechnianie zakłada bowiem pewien aktywizm w 'czynieniu czegoś powszechnym', prezentowanie zaś ma, poza na poły oficjalnym znaczeniem 'pokazywania", także dodatkowo pewien odcień bierności zawarty w znaczeniu 'zostawiać czy przedstawiać coś do oglądania'. Możliwe, że w celu uniknięcia potencjalnych nieporozumień, które mogłyby się pojawić na tym tle, Sąd Najwyższy odwołał się do dobrze znanego z art. 9 k.k. pojęcia zamiaru jako elementu kształtującego nowe rozumienie ,propagowania”. Świadczyć o tym może także pozytywne odniesienie się w tym kontekście składu orzekającego do tezy Gardockiego, że przestępstwo stypizowane w art. 256 in princ. k.k. może być popełnione wyłącznie ze szczególnie zabarwionym zamiarem wyrażenia aprobaty dla takiego ustroju ${ }^{45}$. Wprowadzenie słowa ,prezentowanie” w miejsce „upowszechnianie” miało jednak też inną konsekwencję - o ile upowszechnianie można jeszcze sensownie połączyć z ,ustrojem państwa”, gdyż czynienie jakiegoś ustroju powszechnym może być rozumiane również w znaczeniu "rozpowszechniać ustrój, czynić go dostępniejszym, skuteczniejszym, działającym czy funkcjonującym', o tyle ,prezentowanie ustroju” już jest takich skojarzeń zupełnie pozbawione. Tym samym zaproponowany sposób rozumienia pojęcia „propagowanie" poprzez przybliżenie go za pomocą słowa ,prezentowanie” pozbawia czyn stypizowany w art. 256 k.k. jego pierwotnego, literalnego znaczenia ("upowszechniać, urzeczywistniać ustrój') i przenosi go wyłącznie w sferę doktrynalną ('prezentować wiedzę o ustroju').

Zauważmy jeszcze w tym kontekście, że trzon przedłożonego przez Sąd Najwyższy wyjaśnienia, czym jest ,propagowanie” ('prezentowanie, z zamiarem przekonania'), wbrew początkowej deklaracji o braku bliskoznaczności między

44 OSP 2002, s. 648.

45 L. Gardocki, op. cit., s. 287. Por. też Z. Ćwiąkalski, op. cit., s. 912; O. Górniok, op. cit., s. 309. 
wyrazami „pochwalać” i „propagować”, wskazuje dobitnie, że Sąd Najwyższy uznaje oba pojęcia za synonimiczne. Nie jest bowiem naszym zdaniem prawdopodobne (mimo odmiennego, ale niepopartego przykładami poglądu wyłożonego przez Sąd Najwyższy) zachowanie, które zakładałoby, że osoba prezentująca coś z zamiarem przekonania do tego, nie pochwalałaby jednocześnie owej rzeczy, usługi czy postawy. Jednocześnie jedynie sporadyczne zapewne i inkoherentne byłyby sytuacje, w których ktoś pochwalałby coś i jednocześnie nie chciałby przekonać do tego innych. W naszym przekonaniu przedstawiona przez Sąd Najwyższy interpretacja propagowania w rozumieniu art. 256 k.k., zamiast odseparować go od tradycji wykształconej w kontekście art. 270 § k.k. z 1969 roku, $\mathrm{w}$ istocie pozwoliła zatem na powiązanie go z ,pochwalaniem” i utrwaliła tendencję do prowadzenia egzegezy tego przepisu w stronę ograniczenia wolności wypowiedzi.

Na koniec omawiania tej uchwały Sądu Najwyższego zastanówmy się jeszcze krótko nad językowymi źródłami jej kształtu jurydycznego. Pierwsze, co zwraca uwagę w uzasadnieniu uchwały, to rozbicie zwrotu „propagować ustrój” na dwa elementy i skupienie się składu orzekającego na samym słowie „propagowanie". Drugie - o czym też już szerzej wspominaliśmy — to wątpliwe i niebezpieczne na gruncie prawa karnego materialnego stosowanie synonimiki, dzięki której można było przejść od „propagowania”, przez „upowszechnianie”, do „prezentowania”, co w konsekwencji pozwoliło Sądowi skupić się na kwestiach związanych ze światem idei (myśli), a nie ze światem faktów (zmysłów). Pozostaje nam zatem zatrzymać się jeszcze nad trzecim źródłem językowym treści uchwały, czyli nad samym słowem ,propagować”. Przypomnijmy, że zdaniem Sądu Najwyższego w języku polskim „,propagować” oznacza „przede wszystkim upowszechnianie, szerzenie czegoś, w tym także poglądu, by do tego kogoś przekonać”. Zwrot „przede wszystkim” oznacza, że skład orzekający zdawał sobie sprawę z niepełnego charakteru zaproponowanego przybliżenia znaczenia słowa „propagowanie”, niemniej jednak nie pokusił się o wyjaśnienie, w jakim zakresie pole semantyczne wspomnianego wyrazu zostało przez sąd pominięte.

Przypomnijmy zatem, że ,propagowanie” w znaczeniu rzeczownikowym pochodzi z łaciny, w której występuje słowo propagatio, oznaczające 'rozmnażanie', 'rozszerzanie', 'powiększanie' (stąd też polski wyraz „propagacja”, który oznacza 'rozprzestrzenianie się fal, błędu lub uszkodzenia albo też namnażanie się organizmów') oraz czasownik propagare, którego znaczenie oddają takie słowa, jak: „powiększać”, „rozszerzać”, „rozprzestrzeniać”, „rozmnażać rośliny lub zwierzęta". Przyjmuje się, że słowa propagatio i propagare pochodzą od rzeczownika propago (gen. propaginis), za pomocą którego oznaczano to, co zostało rozprzestrzenione, potomstwo, przychówek, sadzonkę; ten zaś powstał z połączenia przedrostka pro- ('przed' albo 'wobec', 'według', 'z powodu', 'w obronie') oraz 
praindoeuropejskiego tematu *pag- (*pak) - 'zapiąć', 'zawiązać', 'utwierdzić' (którego echo możemy odnaleźć w słowie ,pakt") ${ }^{46}$.

Pominięty przez Sąd Najwyższy (bez wyjaśnienia przyczyny) obszar pola semantycznego pojęcia „,propagowanie” związany jest zatem z uchwytnym także dla współczesnego naturalnego użytkownika języka polskiego aspektem fizycznego rozprzestrzeniania rzeczy $\mathrm{z}$ ich upowszechnianiem w znaczeniu rozsadzania czy rozmnażania. W tym też dopiero sensie użyte przez ustawodawcę słowo ,propaguje” staje się w pełni zrozumiałe jako element ustawowego zwrotu ,propagowanie ustroju". Chodzić tu więc będzie o zakaz podejmowania działań prowadzących do tworzenia i rozprzestrzeniania się pewnego faktu (ustroju ${ }^{47}$ ), a nie wiedzy o faktach, ale też nie będzie to odnosiło się do sfery wolności wyrażania poglądów i tym samym nie będzie wplątywało egzegezy art. 256 k.k. w delikatną materię zgodności wyinterpretowanej normy z art. 54 ust. 1 Konstytucji RP (wolności wyrażania swoich poglądów co do faktów). W naszym przekonaniu uwzględnienie przez Sąd Najwyższy pominiętego aspektu znaczenia pojęcia „propagowanie” pozwoliłoby składowi orzekającemu (ale i doktrynie) na, z jednej strony, zerwanie z antyliberalnym dziedzictwem Kodeksu karnego z 1969 roku, z drugiej zaś - na dostosowanie wykładni do gwarancji praw człowieka i obywatela zawartych w Konstytucji RP z 1997 roku.

Uchwała Sądu Najwyższego z 28 marca 2002 roku zasadniczo spotkała się z aprobatą doktryny. Pierwszy pozytywny komentarz ${ }^{48}$, autorstwa Stanisława Hoca, ukazał się jeszcze w 2002 roku na łamach „Orzecznictwa Sądów Polskich" ${ }^{49}$. Ten jeden z najważniejszych polskich karnistów specjalizujących się w kwestii penalizacji, wcześniej pochwały faszyzmu, a obecnie propagowania ustroju totalitarnego, rozpoczął wywód od krótkiego przypomnienia stanu faktycznego, na którego tle zapadła glosowana uchwała, wzbogaconego o kilka dodatkowych uwag dotyczących polskich grup neofaszystowskich ${ }^{50}$. Warte od-

46 Zob. Proto-Indo-European Etymological Dictionary: A Revised Edition of Julius Pokorny's Indogermanisches Etymologisches Wörterbuch, s. 2281-2282, https://marciorenato.wordpress. com/linguistica-indo-europeia/ (dostęp: 22.02.2019).

47 Pojęcie „ustrój” wyjaśniliśmy w T. Scheffler, Przestępstwo art. 256. Część ogólna, s. 98 100; zob. też przywołaną tam literaturę przedmiotu.

48 Gwoli ścisłości należy odnotować jeszcze w pełni pozytywne omówienie przedmiotowej uchwały SN sporządzone przez Stanisława Zabłockiego, Przegląd orzecznictwa Sądu Najwyższego - Izba Karne, „Palestra” 2002, nr 5-6, s. 145-146. Ponieważ tekst ten jest zasadniczo wiernym powtórzeniem uzasadnienia uchwały, nie będzie on przedmiotem osobnej analizy.

49 S. Hoc, Glosa do uchwaty $S N$ z dnia 28 marca 2002 roku, OSP 46, 2002, nr 12, K 164, s. 648-650. Tezy zawarte w glosie autor ten powtórzył w artykule $O$ przestępstwach z art. 256 K.K., s. $53-60$.

50 Jako źródło wiedzy w tym zakresie przywołany został tekst Jakuba Rzekanowskiego, $W$ cieniu swastyki, zamieszczony w „Trybunie” z dnia 5 czerwca 2002 roku. Jako ciekawostkę można tu przypomnieć, że autor owego artykułu już wówczas był postacią rozpoznawalną z politycznego zaangażowania $\mathrm{w}$ spory ideowe. $\mathrm{W}$ jednej z książek poświęconych walce $\mathrm{z}$ rasizmem można było przeczytać nawet następującą opinię: „Młody dziennikarz Jakub Rzekanowski z dziennika »Trybu- 
notowania jest już samo odwołanie się do kategorii neofaszyzmu, która - jak wcześniej zaznaczyliśmy ${ }^{51}$ - z uwagi na zróżnicowaną treść ma walor wyłącznie publicystyczny i jest zupełnie nieprzydatna dla analizy art. 256 k.k. Pojęcie to nie zostało też wykorzystane przez Hoca w dalszej części glosy. Autor ten skupił się natomiast na zrelacjonowaniu treści uzasadnienia rzeczonej uchwały, zaopatrując poszczególne jego fragmenty w pozytywne komentarze wzbogacone także o literaturę, do której Sąd się nie odwołał. Nie będziemy tu zatem szczegółowo omawiać zawartości glosy i ograniczymy się tylko do dwóch interesujących spostrzeżeń w niej zawartych.

Przede wszystkim zwraca uwage odczytanie przez Hoca przedstawionego przez Sąd Najwyższy wyjaśnienia pojęcia „propagowanie” jako pochłaniającego „pochwalanie”. Wprawdzie możemy w glosie przeczytać, że propagowanie „nie musi być połączone z pochwalaniem” oraz że „określenia te nie są tożsame”, jednak jednocześnie stwierdzono w niej, że „propaganda nie ogranicza się do samego pochwalania, ale zmierza p on ad to [wyr. - T.S.] do przekonania o czymś adresata" ${ }^{2}$. Ten sposób myślenia potwierdza również wzmianka, że art. 256 k.k. jest „,W pewnym stopniu” odpowiednikiem przepisu art. 270 § 2 k.k. z 1969 roku,

na« jest prawdopodobnie liderem na polu badań nad skrajną prawicą w mediach głównonurtowych" - R. Pankowski, M. Kornak, Poland, [w:] Racist Extremism in Central and Eastern Europe, red. C. Mudd, London-New York 2005, s. 145-170, tu: s. 165. Na marginesie można jeszcze zauważyć, że Rafał Pankowski i Marcin Kornak, autorzy przywołanego rozdziału poświęconego „ekstremizmowi rasistowskiemu" w Polsce, w specyficzny sposób prowadzili narrację w tym zakresie. Dobrym przykładem owej specyfiki może być komentarz do informacji, że w listopadzie 1999 roku stowarzyszenie Nigdy Więcej (którego, dopowiedzmy, Kornak był założycielem i prezesem) ogłosiło raport o przemocy w Polsce na tle rasistowskim i ksenofobicznym. „Krótkie notki o raporcie — czytamy w książce - znalazły się wyłącznie w dwóch dziennikach ogólnopolskich: w centroprawicowej »Rzeczpospolitej« oraz w socjaldemokratycznej »Trybunie«" - ibidem, s. 165. Jak widzimy, w jednym przypadku zdecydowano się na umieszczenie gazety w spektrum prawica-lewica, w drugim natomiast przybliżono charakter dziennika poprzez dookreślenie go za pomocą nazwy nurtu politycznego. Zapomniano również dodać (a dla czytelnika anglojęzycznego nie jest to wiedza powszechna), że „Trybuna” była kontynuatorką głównego organu prasowego polskiej partii komunistycznej. Sprawy wydawać by się mogło drobne, jednak mające dużą moc oddziaływania na czytelnika.

51 Zob. T. Scheffler, Przestępstwo art. 256. Część ogólna, s. 105, przyp. 26; oraz w odniesieniu do mieszanych nagminnie z neofaszyzmem neonazizmu i neopoganizmu germańskiego — s. 109-110. Godzi się nadmienić, że już poprzez wykorzystanie przedrostka neo- na oznaczenie danej rzeczy wskazujemy zwyczajowo jej odmienność (mimo „genetycznego" powiązania) od pierwowzoru. W tym znaczeniu paradoksalnie wskazanie, że dana organizacja czy doktryna jest neofaszystowska czy neonazistowska, eliminowałoby ją z bezpośredniego podejrzenia propagowania „ustroju totalitarnego” (,pochwalania faszyzmu”). Taki zarzut musiałby być poprzedzony pogłębioną analizą tego, w jakim zakresie dana doktryna czy dane działania organizacji pozostały naznaczone totalitarnym rysem.

52 S. Hoc, Glosa do uchwaty SN..., s. 649; idem, O przestępstwach..., s. 53. Zwraca tu uwage użycie w miejsce czasownika „propagować” rzeczownika „propaganda”. Hoc powołał się w tym kontekście na opinię Oktawii Górniok zawartą w komentarzu do art. 256 k.k., [w:] O. Górniok, S. Hoc, S.M. Przyjemski, Kodeks karny. Komentarz. t. 3. Art. 117-363, Gdańsk 1999. Por. T. Scheffler, Przestępstwo art. 256 k.k. Część szczególna I, s. 155-156. 
a także wyrażenie pełnej aprobaty dla stanowiska Sądu Najwyższego, że „z wykładni językowej wynika, iż propagowanie to nic innego jak prezentowanie tego ustroju (faszystowskiego), czyli również wystawianie na widok publiczny symboli takiego państwa, czy też wykonywanie określonych gestów odnoszących się do tego ustroju”, z tym zastrzeżeniem, że ,warunkiem penalizacji propagowania faszystowskiego lub innego totalitarnego ustroju państwa” byłby „publiczny charakter tej propagandy" ${ }^{\prime 3}$. W konsekwencji Hoc wyłożył pogląd, że „odpowiedzialności karnej [na podstawie art. 256 k.k. - T.S.] podlega nie tylko ten, kto publicznie pochwala i w ten sposób propaguje rządy A. Hitlera, ale także publicznie prezentuje symbole lub gesty faszystowskie $\mathrm{w}$ zamiarze przekonania innych do takiej ideologii" ${ }^{54}$.

Jak widzimy, mamy tu wprost przedstawioną tezę, że regulacja zawarta w Kodeksie karnym z 1997 roku jest nie tyle odmienna od tej, która znajdowała się w Kodeksie karnym z 1969 roku, ile jest wręcz jej kontynuacją, poszerzającą dodatkowo obszar penalizacji poprzez objęcie nim zachowań, w ramach których bez pochwalania następowałoby przekonywanie do określonych, „zakazanych” ideologii. Zastrzeżenia do takiej interpretacji art. 256 k.k. przedstawiliśmy już wcześniej. Tu, w kontekście powtórzenia przez Hoca podniesionej przez Sąd Najwyższy argumentacji na rzecz możności ustawowej ,penalizacji propagowania faszyzmu", chcielibyśmy już jedynie przypomnieć, że z punktu widzenia reguł demokratycznego państwa prawa ograniczenie wolności wypowiedzi może następować wyłącznie na podstawie jasnego ustawowego zakazu ${ }^{55}$, nie może zaś być wynikiem żmudnego procesu egzegetycznego, w ramach którego (tak jak w tym przypadku) następuje swoiste wyrugowanie realnego wyrażenia ustawowego i zastąpienie go zwrotem pozaustawowym - w miejsce ,propagowanie ustroju faszystowskiego" wprowadza się ,propagowanie faszyzmu”.

Jak już bowiem zaznaczyliśmy w jednym z wcześniejszych artykułów tego cyklu, „doktryna jest czymś szerszym i większym od konkretnych postulatów ustrojowych" 56 , albowiem obejmuje świat myśli i idei, a zatem jest rozprzestrzeniona wśród ludzkich umysłów niezależnie od konkretnych ustrojów politycznych funkcjonujących w poszczególnych państwach. Ale należy też pamiętać, że doktryna jest czymś mniejszym i węższym od ustroju państwa, gdyż jest tylko jednym z potencjalnych elementów współkształtujących ustrój. Zwróćmy przy tym uwagę, że w wypadku ustroju państwa totalitarnego w ujęciu zaproponowa-

53 S. Hoc, Glosa do uchwaty SN..., s. 649; idem, O przestępstwach ..., s. 56. Także tu pojawia się charakterystyczna zastępowalność „,propagowania” i ,propagandy”. Możliwe, że był to wpływ cytowanej przez Hoca pracy Michała Szulczewskiego, Propaganda polityczna (podtytuł nieprzywołany w glosie: Pojęcia - funkcje - problemy, Warszawa 1971), w której faktycznie występowała pewna swoboda w operowaniu oboma pojęciami. Godzi się jednak zaznaczyć, że praca ta nie odnosiła się - co oczywiste - do prawnokarnego zakazu propagowania ustroju totalitarnego.

${ }^{54}$ S. Hoc, Glosa do uchwaty SN..., s. 650; idem, O przestepstwach..., s. 56.

55 Por. L. Garlicki, op. cit., s. 104-114.

56 T. Scheffler, Przestępstwo art. 256. Część ogólna, s. 113. 
nym przez Hannah Arendt doktryna jest wręcz czymś zbędnym dla państwa, jako że jej istnienie mogłoby prowadzić do wniosku, że są jakieś trwałe elementy pozwalające na odróżnianie prawdy od kłamstwa ${ }^{57}$. Przecież nawet gdybyśmy przyjęli, że doktryna jest częścią ustroju państwa, to przecież pozostaje ona właśnie jego częścią, a nie całością — „propagując” część, nie „propaguje się” całości. Takie utożsamienie części z całością (uznanie, że propagowanie części jest równoznaczne z propagowaniem całości) byłoby zasadne wyłącznie w sytuacji, gdybyśmy mieli do czynienia z czymś na kształt fraktali. W przeciwnym razie (a tak jest $\mathrm{w}$ tym wypadku) popełniamy nieświadomie błąd, biorąc pars pro toto, albo godzimy się na wykorzystywanie w prawie karnym pochodzącej z klasycznej retoryki techniki znanej właśnie jako pars pro toto. W obu przypadkach będziemy pozostawać w niezgodzie z oświeceniową i klasyczną tradycją prawa karnego ${ }^{58}$. Już zupełnie na marginesie zauważmy, że — jak się wydaje - w procesie egzegezy przepisów w wypadkach wątpliwych (na przykład w związku z rozbieżną interpretacją znaczenia słów czy zwrotów) powinno wybrać się taką wykładnię, która jest korzystniejsza dla sprawcy.

Kolejna kwestia, która zostanie tu poruszona, dotyczy zamiaru ${ }^{59}$ w odniesieniu do przestępstwa publicznego propagowania ustroju totalitarnego. Jak pamiętamy, Sąd Najwyższy w sposób aprobatywny przywołał tezę Gardockiego, że warunkiem karalności tego czynu jest jego popełnienie wyłącznie ze szczególnie zabarwionym zamiarem wyrażenia aprobaty dla takiego ustroju. Hoc, powołując się dodatkowo na inne głosy doktryny (komentarze wypowiedzi Zbigniewa Ćwiąkalskiego, Oktawii Górniok i Andrzeja Marka), wskazał, że „przestępstwo to może być popełnione tylko $\mathrm{w}$ zamiarze bezpośrednim, co wynika $\mathrm{z}$ intencjonalnego zabarwienia pojęcia »propagowanie«"60. Możliwe, że aby właśnie podkreślić to zawężenie interpretacyjne Sąd Najwyższy wskazał na konieczność rozumienia po-

57 H. Arendt, Totalitarian ideology, [w:] Totalitarianism: Temporary Madness or Permanent Danger?, red. T. Mason, Boston 1967, s. 42 n.; M. Zmierczak, Spory o istote faszyzmu. Dzieje i krytyka, Poznań 1988, s. 136. Por. też T. Scheffler, Przestepstwo art. 256. Czesść ogólna, s. 101-102.

58 Szerzej na ten temat zob. J. Warylewski, Kierunki i szkoly w nauce prawa karnego, [w:] System prawa karnego, t. 1. Zagadnienia ogólne, red. A. Marek, Warszawa 2010, s. 54-70.

59 Szerzej co do zamiaru umyślnego zob. J. Giezek, Typizacja przestępstw oraz jej elementy, [w:] M. Bojarski, J. Giezek, Z. Sienkiewicz, op. cit., s. 111-116.

60 S. Hoc, Glosa do uchwaty SN..., s. 649. Odnotujmy, że zdaniem Zabłockiego (powołującego się w sposób pozytywny na opinię SN) przestępstwo określone w art. 256 k.k. „może być popełnione tylko ze szczególnie zabarwionym zamiarem aprobaty dla takiego [to jest totalitarnego — T.S.] ustroju, ale jeśli z taką intencją jest dokonywane, wówczas może przybrać postać praktycznie każdego zachowania" - idem, op. cit., s. 146. Jak widzimy, zdaniem tego autora elementem decydującym o karalności byłaby tu „intencja” sprawcy, która zresztą miałaby się odnosić nie tyle do działania w postaci propagowania ustroju, ile raczej do jego osobistego stosunku emocjonalnego związanego z ustrojem uznanym przez sąd lub organy ścigania za totalitarny. Ten kierunek interpretacji treści uchwały SN wskazuje na możność odczytania jej jako usankcjonowania analogii w prawie karnym, gdyż penalizowany byłby wówczas czyn realizujący się poprzez każde zachowanie wyrażające aprobatę dla ustroju totalitarnego, nie taka jest zaś treść art. 256 in princ. k.k. 
jęcia „propagowanie” jako działania podjętego „w celu” (tak we wstępnym przybliżeniu pojęcia „propagowanie”) lub „w zamiarze” (tak w finalnym wyjaśnieniu znaczenia pojęcia ,propagowanie") przekonania do ustroju totalitarnego. Warto jednak zauważyć, że o ile sformułowanie „w celu” dosyć jednoznacznie kieruje nas w stronę zamiaru bezpośredniego, o tyle zwrot „w zamiarze" pozostawia możliwość rozpatrywania sprawy również w kontekście zamiaru ewentualnego. Trudno orzec, na ile świadomie skład orzekający odstąpił od pierwotnego „w celu” na rzecz finalnego „w zamiarze”. Faktem pozostaje, że ostateczny kształt odpowiedzi na zagadnienie prawne pozostawia większe pole interpretacyjne w tym zakresie. Nie byłoby jednak zaskoczeniem, gdyby owa zmiana okazała się mimo wszystko intencjonalna, gdyż — jak trafnie przypomniał Hoc — na tle wcześniejszego stanu prawnego Sąd Najwyższy wypracował linię orzeczniczą uznającą możliwość pochwalania i propagowania faszyzmu w zamiarze ewentualnym ${ }^{61}$.

Następne w pełni pozytywne omówienie uchwały Sądu Najwyższego, opublikowane tym razem na łamach „Wojskowego Przeglądu Prawniczego”, zostało sporządzone przez Ryszarda A. Stefańskiego ${ }^{62}$. Autor ten, powołując się na zawarte $\mathrm{w}$ słownikach języka polskiego oraz $\mathrm{w}$ słowniku synonimów ${ }^{63}$ przybliżenia pojęcia „propagować”, doszedł do wniosku, że „propagowaniem faszystowskiego lub innego totalitarnego ustroju państwa, o którym mowa w art. 256 k.k., jest takie zachowanie, które upowszechnia, szerzy, popularyzuje lub lansuje którykolwiek z tych ustrojów i zmierza do pozyskania dla niego zwolenników"64.

Otrzymaliśmy w ten sposób kolejny interesujący przykład skutków stosowania synonimiki w prawie karnym materialnym, dzięki której można było zestawić w ciągu cztery przybliżenia znaczenia słowa „propagować” „upowszechniać”, „szerzyć”, „popularyzować” i „lansować”. Zwróćmy uwagę, że o ile „,upowszechniać” i „szerzyć” w odniesieniu do zwrotu „ustrój państwa” zachowuje jeszcze skojarzenia z działaniami polegającymi na tworzeniu czy umacnianiu realnej struktury polityczno-prawnej istniejącej lub budowanej w danym społeczeństwie,

${ }^{61}$ W wyroku SN z dnia 24 października 1962 roku (sygn. akt II K 446/62) możemy przeczytać następujące stwierdzenie: „Swastyka jest symbolem faszyzmu [...]. Oskarżony sporządziwszy ten symbol, umieścił go na beli płótna, które na taśmie przechodziło do innych działów produkcji. Jeżeli oskarżony wprost nie dążył do publicznego pochwalania faszyzmu i propagowania faszyzmu, to przez rozpowszechnianie jego symbolu co najmniej się godził na efekt swego działania" S. Hoc, Glosa do uchwaty SN..., s. 649-650; idem, Przestępstwo propagandy antypaństwowej w polskim prawie karnym, Wrocław 1981, s. 28.

62 R.A. Stefański, Przegląd uchwat Izby Karnej Sądu Najwyższego w zakresie prawa karnego materialnego, prawa karnego wykonawczego, prawa karnego skarbowego i prawa wykroczeń za 2002 roku, „Wojskowy Przegląd Wojskowy” 2003, nr 1 (225), s. 97-99.

63 Stefański powołał się w tym kontekście na te same pozycji, które przywołał SN: Praktyczny stownik... i Mały stownik..., a w wypadku synonimów: A. Dąbrówka, E. Geller, R. Turczyn, op. cit. Autor wyraził też pogląd aprobujący tezę, że przy egzegezie słowa „propagować” w pierwszej kolejności należy odwołać się do wykładni językowej. Uwaga ta nie spowodowała jednak próby wyjścia poza schemat interpretacyjny narzucony przez SN.

64 R.A. Stefański, op. cit., s. 98. 
o tyle słowa „lansować”, osobliwie zaś „popularyzować”, przenoszą nas już wyłącznie do sfery świadomościowej i doktrynalnej. Co warte podkreślenia, posłużenie się przez Stefańskiego w tym kontekście spójnikiem alternatywy zwykłej „lub” wzmocniło jeszcze dodatkowo psychologiczny efekt przekonujący czytelnika, że w wypadku każdego z czterech słów mamy do czynienia z równoważnymi sytuacjami. Jeżeli jednak przyjrzymy się dokładniej przedstawionej przez autora propozycji odczytania znaczenia wyrazu ,propagować”, zauważymy, że zmierzał on jednak do zinterpretowania wspomnianego czasownika jedynie w kategoriach działań podejmowanych w sferze intelektualnej. Świadczą o tym nie tylko aprobująco przywołane argumenty podniesione przez Sąd Najwyższy (i znajdujące się również we wcześniejszych wypowiedziach doktryny) w zakresie ,szerzenia wiedzy" o takich ustrojach, a także odnośnie do wspomnianych wcześniej ograniczeń penalizacji w przypadku takiego „szerzenia wiedzy”, ale też założenie, że owo „propagowanie” ma zmierzać do „pozyskania” zwolenników danego ustroju.

Przypomnijmy zatem, że w dotychczasowych doświadczeniach związanych z państwami uznawanymi za totalitarne propagowanie ich ustroju odbywało się za pośrednictwem funkcjonowania aparatu terroru, który przy odpowiednim natężeniu i odpowiednich środkach był zdolny - jak znakomicie przedstawił to George Orwell w powieści Rok 1984 - „pozyskać” prawie każdego człowieka i przekształcić go w „zwolennika” władzy totalnej. „Poszerzanie” czy „upowszechnianie" ustroju nie odbywało się bowiem przez przekonywanie ludzi, lecz przez formowanie konkretnych instytucji społecznych, politycznych i administracyjnych totalizujących państwo i społeczeństwo, ubranych następnie w szaty regulacji normatywnych, którym często przyznawano status aktów prawnych ${ }^{65}$. Na marginesie można tu jeszcze wspomnieć, że Stefański część uwag poświęcił wykazaniu, że wyrazy „pochwalać” i „propagować” nie mogą być traktowane jako pojęcia bliskoznaczne, gdyż — jak trafnie podniósł, odwołując się do poglądu Jerzego Wróblewskiego - „utożsamienie znaczeniowe tych przecież różnych określeń pozostawałoby w sprzeczności z dyrektywą interpretacyjną, że bez uzasadnionych powodów nie należy różnym zwrotom nadawać tego samego znaczenia" ${ }^{66}$. W konsekwencji wywiódł tezę, że „dla wykładni art. 256 k.k. w omawianym zakresie nieprzydatne są poglądy wypowiedziane na gruncie art. $270 \S 2$ k.k. z 1969 roku, a dotyczące interpretacji pojęcia »pochwala «"67.

Niestety to jak najbardziej poprawne spostrzeżenie nie zostało zastosowane przez Stefańskiego do jego własnej analizy, gdyż analogicznie jak Hoc bez

${ }^{65} \mathrm{~W}$ polskiej literaturze naukowej proces ten znakomicie został opisany w przypadku Niemiec przez Franciszka Ryszkę (Państwo stanu wyjątkowego. Rzecz o systemie państwa i prawa Trzeciej Rzeszy, Wrocław 1985), a w wypadku Rosji przez Adama Bosiackiego (Utopia. Władza. Prawo. Doktryna i koncepcje prawne „, bolszewickiej” Rosji 1917-1921, Warszawa 1999).

66 R.A. Stefański, op. cit., s. 99. Stefański odwołał się tu do pracy Jerzego Wróblewskiego, Rozumienie prawa i jego wyktadnia, Wrocław 1990, s. 79.

${ }^{67}$ R.A. Stefański, op. cit. 
zastrzeżeń zaaprobował cytowaną już tezę Górniok, że „propaganda nie ogranicza się do samego pochwalania, ale zmierza $\mathrm{n}$ a d to [wyr. - T.S.] do przekonania adresatów o racjonalności i zaletach [...] totalitarnego ustroju"68. Nie tylko zatem autor ten dopuszczał sytuację, gdy pola semantyczne obu pojęć będą się przecinać, ale wręcz zakładał, że czyn w postaci „pochwalania” byłby swoistą bazą, na podstawie której podejmowane byłyby następnie działania dopełniające „propagowania”. Zauważmy, że w ten sposób pochwalanie stało się elementem warunkującym prawidłowe rozumienie słowa „propagowanie”, jednak nie przez deklarowany wcześniej kontrast (różnicę ${ }^{69}$ ), ale przez zaakceptowaną implicite ideę ciągłości (w niektórych przypadkach nawet jedności ${ }^{70}$ ) między art. $270 \S 2$ k.k. z 1969 roku a regulacją znajdującą się w art. 256 k.k. ${ }^{71}$

Wśród publikacji komentujących uchwałę Sądu Najwyższego z 28 marca 2002 roku szczególne miejsce ze względu na częściowo krytyczny wobec treści uchwały wydźwięk zajmuje glosa autorstwa Andrzeja Sakowicza ${ }^{72}$. Punktem wyjścia analizy przedstawionej przez tego autora jest konstatacja, że wolność

68 Ibidem, s. 98.

69 Nie miejsce tu na szersze zajęcie się kwestią pojęcia „różnica”, w szczególności jako niedocenionego wciąż (w stopniu, na jaki zasługuje) narzędzia egzegetycznego w procesie tworzenia i stosowania przepisów prawa. Warto jednak zwrócić uwagę, że cały język (a tym samym także języki: prawny i prawniczy) jest strukturą opartą na różnicach, czy to na poziomie fonemów, czy też na płaszczyźnie leksykalnej. Zapominanie o tym może zatem prowadzić do tworzenia niepoprawnych interpretacji zjawisk językowych. A ponieważ, jak to podniesiono w literaturze przedmiotu, „dokonywanie różnicowania to fundamentalny akt poznawczy służący reorganizacji strumienia zdarzeń" (A. Skibiński, Gregory Bateson i kontekstowa teoria komunikacji. Różnica, która czyni różnice, i wzorzec, który łączy, [w:] Komunikologia. Teoria i praktyka komunikacji, red. E. Kulczycki, M. Wendland, Poznań 2012, s. 69-88, tu: s. 73), to balansowanie pomiędzy tym, co różne, a tym, co takie samo, staje się jednym z ważniejszych wyzwań w egzegezie prawniczej.

70 Stefański przyjąl, że ponieważ „ustawa nie wskazuje formy propagowania”, to kryminalizowane działanie może przyjąć dowolną postać, na przykład „słowną, pisemną, publikacji, a także określonych gestów [...], byle by z zachowania wynikało, że sprawca zmierza do upowszechnienia i przekonania adresatów o racjonalności oraz zaletach faszystowskiego lub innego totalitarnego ustroju" - idem, op. cit., s. 99. Wystarczy zatem, żeby podczas publicznej wypowiedzi pochwalać ów system za jego „racjonalność”, aby doszło do słownego przekonywania innych do ustroju totalitarnego, a tym samym do zlania się czynności sprawczej „pochwalania” i „propagowania” w znaczeniu, o którym pisał Stefański.

71 O sile stereotypu nakazującego odczytywać „propagowanie” w kategorii „pochwalania” mogą świadczyć zdarzające się pomyłki językowe. Dla przykładu w jednym z tekstów poświęconych zagadnieniu przestępstwa podobnego w kontekście art. 256 in princ. k.k. posłużono się nazwą „publiczne pochwalanie propagowania ustroju totalitarnego" — J. Jurewicz, Kryterium podobieństwa przestępstw w ujęciu kodeksu karnego, PiP 2008, nr 11, s. 79.

72 A. Sakowicz, Glosa do uchwaty SN z 28 marca 2002 roku, „Palestra” 2003, nr 3-4, s. 238243.

Studia nad Autorytaryzmem i Totalitaryzmem 41, nr 1, 2019

(C) for this edition by CNS 
wypowiedzi ${ }^{73}$ stanowi jeden z najważniejszych składników demokracji ${ }^{74}$ i dlatego też do wszelkich jej ograniczeń powinno się podchodzić z dużą ostrożnością i rozwagą. Sakowicz przypomniał w związku z tym, że w art. 54 Konstytucji RP brakuje klauzuli walidacyjnej oraz co za tym idzie — wolność wypowiedzi może być moderowana wyjątkowo i wyłącznie na warunkach określonych $\mathrm{w}$ art. 31 ust. 3 Konstytucji. Tym samym każda ingerencja w sferę wolności wypowiedzi musi być „poprzedzona tzw. testem konieczności (proporcjonalności) ograniczenia wolności i praw" "75. Odwołując się ponadto do wiążących Polskę umów międzynarodowych (Europejskiej Konwencji Praw Człowieka i Podstawowych Wolności oraz Międzynarodowego Paktu Praw Obywatelskich i Politycznych), z których wywodzi się zasadę, iż każda ingerencja w wolność wypowiedzi może być podjęta wyłącznie w celu ochrony innego, równie ważnego dobra, oraz że musi być precyzyjnie określona ingerencja przez prawo, Sakowicz wywiódł pogląd, że z tego punktu widzenia komentowana uchwała SN ,zbyt szeroko wyznaczyła granice kryminalizacji faszyzmu lub innego totalitarnego ustroju państwowego na gruncie art. 256 k.k.”, gdyż Sąd ten „,zapomniał”, iż każda „ingerencja musi mieć charakter racjonalny" i pojawiać się jako swoista ostateczność ${ }^{76}$. Innymi słowy, jak stwierdził Sakowicz, polemizując z kontrowersyjną tezą Sądu Najwyższego

73 Zakres wolności wypowiedzi autor ten (odwołując się do tezy wyłożonej przez Marka A. Nowickiego) określił jako możność posiadania poglądów oraz wolność wymiany (też transgranicznie) idei bez ingerencji władz publicznych. Por. M.A. Nowicki, Wokót Konwencji..., s. 288. Powtórzył też za Anną Frankiewicz, że samodzielność decyzyjna i autonomia działania „wyrażają się w możliwości swobodnego poszukiwania, otrzymywania, wyrażania oraz rozpowszechniania poglądów i informacji za pomocą słowa mówionego, pisanego, druku, gestu czy dzieła sztuki" - A. Frankiewicz, op. cit., s. 362. Zob. A. Sakowicz, op. cit., s. 238.

74 A. Sakowicz, op. cit., s. 238. Dla podkreślenia wagi tej konstatacji Sakowicz powołał się na wypowiedź Arystotelesa, że wolność wypowiedzi jest „największym z dóbr zewnętrznych ludzkości”. Pomijając kwestię tego, że cytowana wypowiedź nie znajduje się we wskazanym w przypisie miejscu, jak też to, że „dobra zewnętrzne” stoją wyraźnie niżej w hierarchii ludzkich potrzeb niż dobra duchowe, to i tak warto przypomnieć, że w opinii Arystotelesa „w odniesieniu do dóbr zewnętrznych, za największe [...] z nich uważać będziemy to, co oddajemy bogom, i do czego przede wszystkim dążą ludzie piastujący najwyższe stanowiska, i to, co jest nagrodą za najszlachetniejsze czyny; tym zaś jest cześć (ona bowiem jest największym z dóbr zewnętrznych)" - Arystoteles, Etyka nikomachejska, [w:] idem, Dzieła wszystkie, t. 5, Warszawa 2002, s. 155, 1123b. Jak się wydaje, trafniejsze byłoby przywołanie w tym kontekście przez Sakowicza innej wypowiedzi Arystotelesa, a mianowicie jego stwierdzenia, że „cechą znamienną” demokracji jest wolność (w odróżnieniu od arystokracji, której cechą jest cnota, i oligarchii nacechowanej bogactwem). Co warte przy okazji przypomnienia, zdaniem Arystotelesa ,zasada [...], że wola większości rozstrzyga, obowiązuje wszędzie, bo i oligarchii, i w arystokracji, i w demokracji, a moc rozstrzygająca ma to, co uchwali większość biorących udział w zarządzie państwa" - Arystoteles, Polityka, Warszawa 2012, ks. IV, 6, 4, s. 118, 1294a. Do zagadnienia wolności, prawa i woli większości w arystotelesowskiej koncepcji demokracji wrócimy jeszcze w kolejnym artykule cyklu.

75 A. Sakowicz, op. cit., s. 239. Tak też w przywołanym przez Sakowicza wyroku Trybunału Konstytucyjnego z dnia 26 kwietnia 1995 roku, sygn. akt K 11/94, „Orzecznictwo Trybunału Konstytucyjnego" 1995, nr 1, poz. 12.

76 Ibidem, s. 238, 240, 242.

Studia nad Autorytaryzmem i Totalitaryzmem 41, nr 1, 2019

(C) for this edition by CNS 
dotyczącą konieczności braku tolerancji państwa demokratycznego wobec czynu polegającego na propagowaniu ustroju antydemokratycznego „w zamiarze przekonania" do niego,

wolność wypowiedzi nie może ograniczać się do informacji czy idei, które są akceptowane i uznawane za nieobraźliwe lub naturalne, lecz odnosi się w równym stopniu do takich, które obrażają, oburzają lub wprowadzają niepokój w państwie lub w jakiejś części społeczeństwa. Takie są wymogi pluralizmu, tolerancji oraz otwartego umysłu, bez których nie możemy mówić o „społeczeństwie demokratycznym”. [...] Demokracja — podkreślił Sakowicz — nie jest stałą dominacją opinii większości ${ }^{77}$.

Trudno tu orzec, na ile uczynione zostało to świadomie, ale w cytowanej wypowiedzi odwołano się do wielkiej tradycji liberalnego sposobu pojmowania wolności myśli i słowa, która chyba w najbardziej paradygmatyczny sposób została wyartykułowana przez Johna Stuarta Milla w słynnym eseju $O$ wolności ${ }^{78}$. Przypomnijmy, że może nawet nie tyle istotne jest to, że ten współtwórca dominującego we współczesnej Europie ustroju demoliberalnego uznawał wolność opinii i jej wyrażania za warunek sine qua non „duchowego szczęścia ludzkości (od którego wszelka inna pomyślność zależy)", bo takie sformułowanie mogłoby dziś uchodzić za wytarty frazes, ale to, że z wolności głoszenia poglądów nawet najbardziej skrajnych i obrazoburczych dla opinii publicznej uczynił znamię cywilizowanego, racjonalnego i liberalnego społeczeństwa i państwa.

Dziwne to - szydził Mill z rzekomych zwolenników wolności — że ludzie przyjmują prawdziwość argumentów na korzyść swobodnej dyskusji, lecz oponują przeciw „wyciąganiu z nich krańcowych wniosków", nie rozumiejąc, że jeśli te racje nie są dobre w krańcowym wypadku, to nie wystarczą i w żadnym innym. Dziwną też jest rzeczą, że nie widzą oni swoich pretensji do nieomylności, gdy uznają, że powinno się swobodnie roztrząsać wszystkie przedmioty, które mogą być wątpliwe [kursywa w tekście - T.S.], ale sądzą, że należy zakazać kwestionowania jakiejś zasady lub doktryny, ponieważ ona jest tak pewna [kursywa w tekście - T.S.]; to znaczy ponieważ oni są pewni [kursywa w tekście — T.S.], że ona jest pewna. Nazywać jakieś twierdzenie pewnym, gdy jest ktoś, kto zadałby mu kłam, gdyby mu na to pozwolono, ale tego

77 Ibidem, s. 243. W wypowiedzi Sakowicza możemy odnaleźć wpływ nie tylko Johna Stuarta Milla (o czym dalej), ale również koncepcji „społeczeństwa otwartego” Karla Raimunda Poppera. Przypomnijmy, że zdaniem tego wybitnego filozofa nauki „wolność polityczna” walczy z każdą postacią despocji, a więc zarówno z tyranią jednostki, jak i „tyranią większości”, nawet gdyby była ona sprawowana w imię najpiękniejszych ideałów i haseł. „[P]od rządami despotycznymi — przypomniał we wstępie do polskiego wydania Społeczeństwa otwartego — [...] jesteśmy zastraszeni, i nie mamy prawa do odpowiedzialności za własne czyny. To oznacza, że jesteśmy odarci z naszego człowieczeństwa. Częścią naszego człowieczeństwa bowiem jest moralna odpowiedzialność. Wolność polityczna [...] jest społecznym warunkiem życia ludzi moralnie odpowiedzialnych" K.R. Popper, Przedmowa do czytelnika polskiego, [w:] idem, Spoleczeństwo otwarte i jego wrogowie, t. 1. Urok Platona, Warszawa 1993, s. 11.

78 Szerzej zob. M. Urbańczyk, op. cit., s. 85-96. 
pozwolenia nie posiada, znaczy pasować nas samych i tych, którzy się z nami zgadzają, na sędziów pewności, i to sędziów, którzy nie wysłuchają strony przeciwnej ${ }^{79}$.

Czytając klasyków, możemy sobie uświadomić, jakim wyzwaniem dla naszych przyzwyczajeń i nawyków myślowych może stać się zgoda na wolność głoszenia opinii obrazoburczych wobec tego, co współczesne społeczeństwa (albo elity społeczne) uznały za tabu bądź swoiste świeckie sacrum.

Ani podniesione wątpliwości interpretacyjne związane granicami wyznaczonymi przez Konstytucję, ani deklaracja, że granice wolności wypowiedzi w państwie demokratycznym muszą być wyznaczane inaczej niż w państwie totalitarnym i że w związku z tym ,autorzy kodeksu z 1997 roku poczynili daleko idące zmiany" w stosunku do wcześniejszych regulacji, nie skłoniły Sakowicza do podjęcia refleksji nad rzeczywistym znaczeniem zwrotu ,propagować ustrój państwa". Z przedstawionej w glosie argumentacji wynika wręcz, że także ten autor pozostał pod przemożnym wpływem odczytywania regulacji zawartej w art. 256 k.k. w duchu art. 270 § 2 k.k. z 1969 roku. Świadczyć o tym może zarówno błąd popełniony w cytowanym już sformułowaniu, że Sąd Najwyższy „zbyt szeroko wyznaczył granice kryminalizacji propagowania faszyzmu” (zamiast „propagowania faszystowskiego ustroju państwa”), jak i podnoszone przez niego racje na rzecz zawężenia odpowiedzialności na podstawie przepisu art 256 k.k. („,szczególnie zabarwiony zamiar w y ra żen i a a pro ba ty dla ustrojów totalitarnych", „bardziej aktywne, zaangażowane działanie, skierowane na przekonanie

79 J.S. Mill, O wolności, [w:] idem, Utylitaryzm. O wolności, Warszawa 2005, s. 116. Przyczyny, dla których zdaniem Milla nie powinno być ograniczeń wolności słowa, są następujące: „Po pierwsze, jeśli zmuszamy jakąś opinię do milczenia, nie możemy być pewni, że nie jest ona prawdziwa. Zaprzeczać temu oznacza zakładać swoją własną nieomylność. Po drugie, choćby opinia, której kazano zamilknąć, była błędem, może ona zawierać i zwykle zawiera cząstkę prawdy. Ponieważ ogólna lub panująca opinia w jakimkolwiek przedmiocie rzadko lub nigdy nie jest całą prawdą, reszta prawdy może do nas dotrzeć tylko dzięki kolizji między przeciwnymi opiniami. Po trzecie, nawet jeśli przyjęta opinia jest całkowicie prawdziwa, lecz nie może ścierpieć, by ktoś ją mocno i poważnie zwalczał, będzie wyznawana przez większość tych, którzy ją przyjmują, podobnie jak przesąd, bez głębokiego zrozumienia lub odczucia jej uzasadnienia. I [...] po czwarte, znaczenie samej doktryny zaginie lub osłabnie i utraci swój żywotny wpływ na postępowanie i charakter; dogmat stanie się czczą formalnością i zamiast skłaniać do dobrego, będzie tylko zajmować miejsce, nie dopuszczając do rozwijania się rzeczywistych i gorących przekonań wyrosłych z rozumu lub osobistego doświadczenia" - ibidem, s. 152. Pozwoliliśmy sobie na przytoczenie tych dłuższych fragmentów wypowiedzi Milla, aby na tej kanwie wyjaśnić pewne potencjalne nieporozumienie, jakie mogłoby się pojawić w związku z dowodzonymi przez nas dwiema tezami głównymi cyklu naszych artykułów: po pierwsze, wynik interpretacji art. 256 in princ. k.k. uzależniony jest od przedzałożenia doktrynalnego przyjmowanego przez interpretatora; po drugie, przyjęcie perspektywy liberalnej pozwala uzyskać treść normy pozostającej w zgodzie z regulacją zawartą w art. 54 ust. 1 Konstytucji RP oraz z art. 42 ust. 1 Konstytucji RP (zasadą nullum crimen sine lege). Zdajemy sobie bowiem sprawę, że wynik takiej egzegezy jest niezgodny z utrwalonym sposobem wykładania rzeczonego przepisu kodeksu karnego oraz sprzeczny z potrzebami zgłaszanymi przez większość opinii publicznej. Niemniej jednak wyrażamy nadzieję, że nasze tezy będą rozpatrywane jako głos w dyskusji naukowej, a zatem w duchu, którego przestrzegania domagał się John Stuart Mill. 
adresata do totalitarnego ustroju”, ,manifestacja własnych poglądów bez zamiaru przekonania kogokolwiek" [wyr. - T.S.]). Zarzut Sakowicza nie kwestionował zatem zasadności rozdzielenia zwrotu „propagować ustrój”, lecz sprowadzał się wyłącznie do stwierdzenia, że zastosowana przez Sąd wykładnia była rzekomo błędnie „stricte językowa”, co jakoby miało pociągać za sobą „zbyt szerokie” rozumienie słowa „propagować”. Zdaniem Sakowicza bardziej trafne byłoby w tym wypadku prowadzenie wykładni celowościowej „zwrotu »propagowanie «”, gdyż ta uwzględniałaby „ratio legis art. 256 k.k.”, którym w przekonaniu autora była „ochrona porządku prawnego i pokoju społecznego w demokratycznym państwie oraz uchronienie go od zagrożeń o charakterze politycznym lub ideologicznym" $"$.

Jak widzimy, i w tym wypadku ujawnia się stanowisko Sakowicza, zgodnie z którym art. 256 k.k. odnosi się nie tyle do kwestii ustrojowych, ile raczej do światopoglądowych. Zupełnie niepotrzebne zamieszanie, jakie takie podejście generuje, objawiło się w dosyć zaskakującej konstatacji, że „o ile kryminalizację propagowania faszyzmu (sic!) można thumaczyć w Polsce względami emocjonalnymi, gdyż doktryna faszystowska kojarzy się w Polsce ze zbrodniami hitlerowskimi, o tyle $[\ldots]$ szerokie określenie »totalitaryzm « nie daje gwarancji racjonalnego i jasnego określenia tego przepisu". Co warte odnotowania, Sakowicz uznał, że taka redakcja art. 256 k.k. „stwarza możliwość ograniczenia głoszenia i pochwalania innych poglądów politycznych niż demokratyczne i liberalne"81.

Zauważmy, że Sakowicz powtórzył tu prawie dosłownie opinię Lecha Gardockiego wyrażoną jeszcze w 1993 roku na tle ówczesnej wersji projektu nowego kodeksu karnego. Odnotowanie tej różnicy czasowej jest istotne, gdyż w artykule Gardockiego możemy przeczytać: „Osobny problem stanowi kryminalizacja pochwalania faszyzmu (obecnie art. $270 \S 2$ k.k.). Projekt proponuje (art. 255) kryminalizację pochwalania faszyzmu lub »innego totalitarnego ustroju państwa«, a więc jest to próba szerszego ujęcia tego typu przestępstwa" ${ }^{82}$. Gardocki jednoznacznie wskazywał zatem, że mieliśmy wówczas do czynienia z propozycją kryminalizacji „pochwalania” doktryny lub „ustroju totalitarnego”, a nie z zakazem ich „propagowania”. Jak zaś staramy się systematycznie wykazać, jest to różnica znacząca nie tylko w zakresie zmiany znamienia czasownikowego, lecz także w odniesieniu do przedmiotu działania, czyli odejścia od doktryny na rzecz ustroju państwa. Jeżeli weźmie się pod uwagę ową odmienność redakcyjną stanu projektu z 1993 roku, to zrozumiały stanie się niepokój dotyczący pochwalania ustroju totalitarnego. „Twórcy projektu — zauważył Gardocki — mieli, jak można się domyślać, zamiar kryminalizacji pochwalania zbrodni i nadużyć systemu komunistycznego". Ale, jak podnosił, sformułowania zakazujące zarówno po-

80 A. Sakowicz, op. cit., s. 241.

81 Ibidem.

82 L. Gardocki, Granice wolności słowa w projekcie kodeksu karnego, „Palestra” 1993, nr 12, s. 103-106, ten i następne cytaty ze s. 105-106. 
chwalania doktryny, jak i ustroju totalitarnego były zbyt nieostre i przekraczały granice „racjonalnej ingerencji prawa karnego”. Rozwiązanie autor widział w kryminalizacji „pochwalania przestępstwa”, gdyż „obejmie ona również pochwalanie zbrodni popełnianych w ramach realizacji skrajnych doktryn politycznych, a jednocześnie nie zagrozi nadmiernym ograniczaniem wolności słowa". Niestety ani Gardocki (jak pokazaliśmy to w poprzednim artykule), ani Sakowicz nie wywiedli z tych różnic językowych ${ }^{83}$ narzucającego się wniosku, że nowa redakcja przepisu art. 256 k.k. zrywa radykalnie z wcześniejszą tradycją i tworzy zupełnie nowy typ przestępstwa.

Przytoczona wypowiedź Sakowicza dotycząca możliwości ograniczenia głoszenia i pochwalania innych poglądów politycznych niż demokratyczne i liberalne warta jest jednak uwagi z kilku innych powodów. Po pierwsze, wskazuje bardzo wyraźnie na Millowski rodowód rozumienia (zarówno przez niego, jak i przez Gardockiego) źródła ustroju ukształtowanego po 1989 roku i utrwalonego następnie przez Konstytucję RP z 1997 roku (demoliberalizm), a zatem także na zasadność doktrynologicznej krytyki egzegezy art. 256 k.k., prowadzonej z punku widzenia zgodności wykładni przepisów z panującym systemem intelektualno-aksjologicznym. Po drugie, oddaje zastanawiający, biegunowy ogląd panoramy światopoglądowej, w ramach której wszystko, co nie jest „,demokratyczne i liberalne", mogłoby zostać uznane za totalitarne. Przypomnijmy, że dychotomiczny sposób ujmowania rzeczywistości należy do jednego z podstawowych sposobów rozumienia i interpretacji świata ${ }^{84}$, niemniej jednak nie w każdym wypadku trafnie oddaje rzeczywistość. Poszukiwanie przeto „opozycji binarnych” może być uznane za intrygujące narzędzie ułatwiające zrozumienie ukrytych wzorów kultury czy mitów i w tym kontekście pomocne w zrozumieniu nieuświadomionych i nieujawnionych czynników kształtujących tworzenie lub stosowanie przepisów prawnych albo $\mathrm{w}$ analizie zachowań czy stereotypów politycznych (będących przecież częścią kultury), jednakże w przypadku mapy nurtów politycznych staje się narzędziem nieadekwatnym, gdyż mamy tu do czynienia ze spektrum postaw, a nie z duopolem. Po trzecie wreszcie, daje nam kolejny dowód na rzecz niepoprawności przyjmowania, że zakaz propagowania ustroju państwa można prawidłowo interpretować jako zakaz propagowania doktryny. Sakowicz uznał bowiem, że

zamiarem kodyfikatorów z pewnością było objecie dyspozycją art. 256 k.k. komunizmu, jednak określeniem „inny totalitarny ustrój” można objąć propagowanie nie tylko te o ri i [wyr. - T.S.] K. Marksa, ale również rozszerzyć na wcześniejszych myślicieli komunizmu

83 Por. J. Wróblewski, op. cit., s. 79.

84 Por. A. Szabelska, Claude Lévi-Strauss i strukturalna analiza mitu a przyczynek do badań kognitywnych, „Via Mentis” 2012, nr 1, s. 99-108, szczególnie s. 106. 
— G. Winstaleya [tak w oryginale — T.S.], G. Babeufa oraz ortodoksyjnych liberałów uznających, że nieograniczona demokracja jest „totalitarna” ${ }^{25}$.

Niebezpieczeństwo związane z krytykowaną przez nas linią interpretacyjną ujawniło się w cytowanej wypowiedzi w pełnym wymiarze. Zasadniczo trudno jest bowiem orzec, dlaczego unormowaniem zawartym w art. 256 in princ. k.k. (przy założeniu, że penalizuje ono propagowanie postawy światopoglądowej uznanej za totalitarną) nie mielibyśmy objąć propagowania poglądów Babeufa. Szczególnie jeżeli przyjęlibyśmy przedstawione przez Sakowicza ratio legis tego przepisu, czyli między innymi ochronę pokoju społecznego i uchronienie go od zagrożeń politycznych i ideologicznych. Przypomnijmy, że Babeuf zakładał przecież konieczność zniesienia własności prywatnych i wprowadzenie powszechnej równości ekonomicznej za pomocą przemocy (zbrojnego przewrotu), którą zorganizowałaby zakonspirowana grupa spiskowców ${ }^{86}$. Albo na jakiej podstawie mielibyśmy odmówić ścigania propagowania totalitarnych poglądów Lenina i jego dzisiejszych popularnych w środowiskach intelektualnych admiratorów, takich jak Slavoj Žižek ${ }^{87}$ ? Przyjęcie, że propagowanie ustroju państwa nie może być

85 A. Sakowicz, op. cit., s. 241-242. Dla porządku zwróćmy uwagę, że przywołany przez Sakowicza inicjator ruchu diggerów nazywał się Gerrard Winstanley, natomiast imiona twórcy Sprzysiężenia Równych, czyli Babeufa, brzmiały François Noël. Pojawiający się tu skrót G. pochodzi od pseudonimu Babeufa: Gracchus. Kwestią totalitarnej demokracji zajmujemy się w artykule poświęconym interpretacjom przestępstwa propagowania ustroju totalitarnego (art. 256 in princ. k.k.) powstałym po 2009 roku. W tym miejscu zauważmy tylko, że wypowiedź Sakowicza odnosząca się do „ortodoksyjnych liberałów” jest niejasna. Trudno bowiem orzec, czy chodziło mu o to, że „ortodoksyjny liberalizm", ze względu na oskarżanie demokracji o totalitaryzm, będzie mógł być traktowany jako teoria totalitarna (ustrój totalitarny), czy też o to, że głoszenie teorii demokratycznych zostanie zakazane, z uwagi na ich — zdaniem ,ortodoksyjnych liberałów” — totalitarny potencjał.

86 Szerzej zob. L. Kołakowski, Główne nurty marksizmu. Powstanie - rozwój - rozkład, Londyn 1988, s. 155-157.

87 Por. S. Žižek, Rewolucja u bram. Pisma wybrane z roku 1917 W.I. Lenina, Kraków 2007. Pozwolimy sobie przy tej okazji na zacytowanie większego fragmentu wypowiedzi Žižka, gdyż w zastanawiający sposób koreluje ona z sposobem argumentacji, z którym spotykamy się w kontekście art. 256 k.k., i pozwala - jak się wydaje — na zrozumienie pewnych zawartych w dyskursie wokół art. 256 k.k. inkoherencji i idiosynkrazji. Otóż jak zauważył Žižek, „zajęcie się Leninem od razu rodzi [...] zastrzeżenia: tak, dlaczego nie, żyjemy w liberalnej demokracji, mamy wolność i możemy myśleć, o czym chcemy ... oczywiście o ile traktujemy Lenina w sposób »obiektywny, krytyczny i naukowy«, a nie podchodząc do niego z nostalgicznym uwielbieniem, i jeśli ponadto przyjmujemy perspektywę mocno osadzoną $\mathrm{w}$ politycznym porządku demokracji, $\mathrm{w}$ horyzoncie praw człowieka - chodzi o bolesną lekcję, jaką możemy wyciągnąć z doświadczeń XX-wiecznego totalitaryzmu. Cóż da się na to odpowiedzieć? [...] »Wierność demokratycznemu konsensusowi« oznacza akceptację obecnego porządku [...], który wyklucza na wstępie jakiekolwiek poważne zakwestionowanie sposobu, w jaki porządek liberalno-demokratyczny sam jest zamieszany w fenomen, który oficjalnie potępia. [...] Mówiąc w skrócie, oznacza to: mów i pisz cokolwiek ci się podoba - pod warunkiem, że nie kwestionujesz ani nie zakłócasz obowiązującego konsensusu. Wszystko jest dozwolone, nawet pochwalane, jako temat krytyczny: perspektywa globalnej katastrofy ekologicznej; pogwałcenia praw człowieka; seksizm, homofobia, antyfeminizm [...]. Nie ma dziś nic łatwiejszego, niż dostać [...] pieniądze na multidyscyplinarne projekty badawcze dotyczące 
traktowane jako równoznaczne z propagowaniem wiedzy o takim ustroju lub z propagowaniem doktryn politycznych i prawnych uznanych za totalitarne, pozwoliłoby zarówno na uniknięcie tego problemu, jak i na zerwanie z totalitarnym dziedzictwem regulacji prawnych pochodzących z okresu PRL.

Kończąc omawianie glosy Sakowicza, odnotujmy jeszcze przedstawioną przez niego propozycję zmiany sposobu rozumienia wyrazu ,propagowanie”. W ujęciu tego autora pojęcie to powinno oznaczać „publiczne prezentowanie z zamiarem aprobaty i przekonania do faszystowskiego lub innego totalitarnego ustroju państwa”. Różnica w stosunku do treści przedstawionej w glosowanej uchwale Sądu Najwyższego sprowadza się przeto wyłącznie do dodania słowa „aprobaty”. Pomijając pewną niezręczność językową związaną z wystąpieniem zwrotu „zamiar aprobaty” (bardziej poprawne, a oddające jednocześnie — jak się wydaje - intencję autora byłoby sformułowanie „publiczne, aprobujące prezentowanie"), należy uznać, że wyznaczony w ten sposób kierunek egzegetyczny byłby bliższy liberalnej zasadzie ochrony wolności wypowiedzi. Sam Sakowicz podsumował własną propozycję w następujący sposób:

Tylko w takim przypadku [przyjęcia zmodyfikowanego rozumienia słowa „propagowanie” T.S.] ideologii faszystowskiej i innym totalitarnym ustrojom należy się odpór w drodze sankcji karnej, w pozostałych przypadkach właściwym lekiem jest publiczna debata, a nie prawo karne, które powinno mieć charakter ostatecznej reakcji - ultima ratio ${ }^{88}$.

Jednakże także w tym wypadku, jak możemy przeczytać, potwierdzone zostało utożsamienie ustroju państwa $\mathrm{z}$ doktryną (ideologia).

Jak już wspomnieliśmy, uchwała Sądu Najwyższego z 28 marca 2002 roku utrwaliła tendencję do interpretowania art. 256 k.k. jako zakazu propagowania określonych doktryn. Ten sposób egzegezy rzeczonego przepisu stał się typowy dla zdecydowanej większości wypowiedzi zawartych w literaturze przedmiotu (o dwóch głosach odmiennych będziemy jeszcze wspominać), nawet gdy dany autor nie odwoływał się wprost do stanowiska Sądu. Przykładem tego ostatniego podejścia może być komentarz do art. 256 k.k., popełniony przez Michała Kali-

tego, jak walczyć z nowymi formami etycznej, religijnej lub seksistowskiej przemocy. Problem w tym, że wszystko to pojawia się na tle fundamentalnego Denkverbot: zakazu myślenia. Dzisiejsza liberalno-demokratyczna hegemonia jest podtrzymywana przez swego rodzaju niepisany Denkverbot [...]. Ideologiczna funkcja nieustannych odniesień do Holocaustu, Gułagu, a ostatnio do katastrof w Trzecim Świecie służy podtrzymaniu owego Denkverbot, wciąż przypominając nam, że przecież mogło być znacznie gorzej. [...] Domaganie się »naukowej obiektywności« staje się tylko kolejną wersją tego samego Denkverbot [...]. Dziś, prawdziwa wolność myślenia oznacza wolność kwestionowania panującego liberalno-demokratycznego, "postideologicznego « konsensu - albo nie znaczy nic. Oto »leninowskie« stanowisko, z którego nie można ani nie powinno się ustępować" — idem, Postowie. Wybór Lenina, [w:] idem, Rewolucja..., s. 303-306.

${ }^{88}$ A. Sakowicz, op. cit., s. 242. 
towskiego ${ }^{89}$. Autor ten przyjął, że przedmiotem ochrony komentowanego przepisu są ,zasady demokracji, z którymi idee totalitaryzmu [...] są sprzeczne”. Teza ta, powtarzana w bardzo wielu wcześniejszych i późniejszych opracowaniach, także w tym wypadku nie została niestety rozwinięta. Trudno zatem ustalić, o jakie konkretnie zasady demokracji chodziło ${ }^{90}$. Można jedynie przypuszczać, że za tym enigmatycznym sformułowaniem kryło się odwołanie do zasad liberalnej demokracji.

Kalitowski uznał też, że „faszystowski ustrój państwa to ustrój oparty na założeniach faszyzmu jako formy totalitarnej, antydemokratycznej dyktatury nacjonalistycznej, kierującej się w swej polityce szowinizmem i rasizmem". Teza ta, będąca wyrazem potocznego pomieszania faszyzmu z nazizmem, nie wydaje się przydatna w jakichkolwiek analizach art. 256 k.k., gdyż nie pozwala nam na jednoznaczne wyodrębnienie ustroju faszystowskiego spośród innych ustrojów „antydemokratycznych” (w znaczeniu zapewne ,niebędących ustrojami liberalno-demokratycznymi"), takich jak na przykład ustrój Polski po zamachu majowym czy ustrój Hiszpanii po objęciu władzy przez gen. Francisco Franco. Również dodatek wskazujący na szowinizm i rasizm jako cechy ustroju faszystowskiego jest wątpliwy, bo - jak już to thumaczyliśmy w pierwszej części cyklu — zaakceptowanie takiego podejścia powodowałoby uznanie Włoch Mussoliniego, przynajmniej do 1938 roku, za państwo nietotalitarne.

Zamieszanie terminologiczne wzmagała dodatkowo uwaga Kalitowskiego, że inny totalitarny ustrój państwa, o którym mowa w komentowanym przepisie, to „ustrój podobny do faszystowskiego". Wydaje się, że lapidarność tych sformułowań jest jednak zbyt duża, aby można było racjonalnie wyjaśnić, co oznacza „ustrój podobny do faszystowskiego" (gdyż nie chodzi tu raczej o narodowy socjalizm, jako że jego elementy zostały włączone do wyjaśnienia pojęcia „ustrój faszystowski") i jaki stopień podobieństwa decydowałby o możności stosowania art. 256 k.k. w ramach represji karnej (dla przykładu: czy niekierowanie się szowinizmem lub rasizmem powodowałoby, że dany ustrój przestałby być totalitarny, czy też, że należałoby go zaliczyć do ustrojów totalitarnych podobnych do faszystowskiego?). Gwoli ścisłości odnotujmy jeszcze, że zdaniem Kalitowskiego innym ustrojem „może [...] być również, zgodnie z art. 13 Konstytucji RP, ustrój komunistyczny". Ponieważ także ta uwaga nie został szerzej rozwinięta, możemy wyłącznie przypuszczać, że zdaniem autora zakres kryminalizacji głoszenia ide-

89 M. Kalitowski, Komentarz do art. 256, [w:] Kodeks karny. Komentarz, red. O. Górniok, Warszawa 2004, s. 733. Cytaty w tekście będą pochodzić z tej publikacji.

90 O problematyczności automatycznego przeciwstawiania totalitaryzmu i demokracji, szczególnie w kontekście totalistycznych elementów demokracji w koncepcji Jana Jakuba Rousseau, już wspominaliśmy; por. T. Scheffler, Przestępstwo art. 256 k.k. Część szczególna I, s. 153. Zagadnieniem tym — jak już zapowiedzieliśmy — zajmiemy się również w następnym artykule, tam też wspomnimy o opracowanej przez Sartoriego teorii demokracji, dzięki której polscy autorzy zakładający istnienie dychotomii demokracja-totalitaryzm mogliby uzyskać podbudowę teoretyczną dla takiego modelu. 
ologii totalitarnych wyznacza przywołany przepis Konstytucji, a zatem wyklucza zasadniczo represję karną na podstawie art. 256 k.k. wobec doktryn neofaszystowskich lub neonazistowskich.

Przejdźmy teraz do zagadnienia propagowania. Zdaniem Kalitowskiego „propagowanie” oznaczało „szerzenie, upowszechnianie idei, haseł, myśli, zjednywanie kogoś dla jakiejś idei, akcji itp., prowadzenie propagandy". Podkreślał, że owo działanie musi być publiczne, docierać do większej liczby osób oraz musi dążyć do zjednania lub zachęcania do danej idei, co miałoby się wiązać z jej pozytywną oceną przez propagującego. Jak mogliśmy się przekonać, przedstawiona koncepcja, choć bez powtarzania sfomułowań zawartych w omawianej uchwale Sądu Najwyższego, nie odbiegała więc zasadniczo od wyznaczonego przez to orzeczenie sposobu interpretacji czynu publicznego propagowania ustroju totalitarnego. Wydaję się ona też bardziej zakotwiczona we wcześniejszych wypowiedziach literatury przedmiotu niż w rozstrzygnięciach judykatury.

Kolejna wypowiedź doktryny dotycząca przestępstwa propagowania ustroju totalitarnego, o której chcielibyśmy tu wspomnieć, znalazła się w zredagowanym przez Alicję Grześkowiak podręczniku do prawa karnego ${ }^{91}$. Autorem interesującego nas fragmentu jest Radosław Hałas, który trafnie przyjął, że w art. 256 k.k. doszło do kryminalizacji dwóch odrębnych czynów, godzących — jak zaznaczył — „w porządek prawny wynikający z fundamentalnych zasad ustrojowych Rzeczypospolitej Polskiej, a przede wszystkim — w zasadę demokratycznego państwa prawnego"92. Jest to bardzo interesująca konstatacja, bo przyjęcie jej doniosłości mogłoby doprowadzić do uznania, że propagowanie ustroju należałoby rozumieć właśnie jako dążenie do tworzenia, rozbudowywania i upowszechniania instytucji politycznych i prawnych totalizujących społeczeństwo lub państwo. Zwróćmy bowiem uwagę, że o ile nawoływanie do nienawiści można uznać za czyn bezpośrednio godzący w porządek prawny (zasadę pokojowego współistnienia obywateli w pluralistycznym społeczeństwie), o tyle głoszenie jakiejś doktryny przewidującej możliwość stworzenia ustroju totalitarnego (z zamiarem przekonania do takiego ustroju) samo w sobie nie narusza fundamentalnych zasad ustrojowych RP, osobliwie zaś zasady demokratycznego państwa prawnego. Cechą takiego państwa jest bowiem ochrona wolności wypowiedzi, nawet takich, które mogą być traktowane jako obrazoburcze wobec powszechnie akceptowanych wartości i przekonań lub które nawet proponują radykalną przebudowę ustrojową państwa. Dopiero potencjalna skuteczność takiego „głoszenia” mogłaby doprowadzić do pojawienia się czynów, których treścią byłoby tworzenie określonego ustroju totalitarnego, i dopiero takie działania mogłyby zostać uznane za godzące w fundamentalne zasady ustrojowe państwa polskiego. Samo zatem wyrażanie opinii i namawianie do ich akceptacji, jeżeli bezpośrednio nie wywołują one konfliktu

91 Prawo karne, red. A. Grześkowiak, Warszawa 2007, s. 348-349.

92 Ibidem, s. 348. 
społecznego, mieści się jak najbardziej w porządku prawnym Rzeczypospolitej Polskiej i jest zgodne z podstawowymi zasadami ustrojowymi państwa. Hałas nie przyjął jednak wspomnianej konsekwencji własnej opinii i uznał trafność linii interpretacyjnej wyłożonej przez Sąd Najwyższy. Wyjaśniając bowiem, czym jest propagowanie ustroju totalitarnego, powtórzył za nim, że jest to

każde zachowanie polegające na publicznym prezentowaniu takiego ustroju podjętym w zamiarze przekonania do niego. Propagowaniem - uściślił — będzie upowszechnianie myśli $\mathrm{i}$ haseł określających założenia (naczelne zasady) takiego ustroju, połączone z zaangażowaniem sprawcy wyrażającym się w zachęcaniu do poparcia ich i zjednywaniu zwolenników ${ }^{93}$.

Tak jak w wypadku koncepcji Kalitowskiego, propagowanie zostało tu całkowicie zepchnięte w sferę światopoglądową. Dodajmy tu jeszcze dla porządku, że starając się wskazać cechy totalitaryzmu, Hałas oparł się na definicji skonstruowanej przez Friedricha, eliminując z niej jednak - co charakterystyczne - monopol państwa na broń. Nie przyjął również jako znamienia totalitaryzmu wprowadzonej do koncepcji Friedricha przez Brzezińskiego cechy w postaci centralizacji gospodarki. Co jednak ciekawe, w to miejsce Hałas wprowadził nowy, warty uwagi, wyznacznik totalitaryzmu w postaci „utrzymywania przekonania o zagrożeniu ze strony wrogów zewnętrznych i wewnętrznych"94. Zaproponowane przez autora rozumienie totalitaryzmu należy uznać za interesujące, niemniej jednak warto byłoby je uzupełnić o podkreślany przez Friedricha (i Brzezińskiego) element w postaci łącznego występowania wspomnianych markerów dla możności uznania, że mamy do czynienia z ustrojem totalitarnym ${ }^{95}$.

Do problematyki wykładni art. 256 in princ. k.k. wracał w kolejnych latach również wspomniany już Ryszard A. Stefański ${ }^{96}$. Autor ten analizę treści art. 256 k.k. rozpoczął od przypomnienia treści art. 2 i 13 Konstytucji RP oraz art. 20 Międzynarodowego Paktu Praw Obywatelskich i Politycznych oraz stwierdzenia,

93 R. Hałas, Komentarz do art. 256 kk. [w:] Prawo karne, s. 349.

94 Możliwe, że Hałas uczynił to pod wpływem platońskiej analizy tyranii (por. Platon, Państwo, Kęty 1999, ks. IX, s. 281-286, 571-576) albo był to wpływ koncepcji Arendt o „wrogu obiektywnym” (zob. T. Scheffler, Przestępstwo art. 256 k.k. Część ogólna, s. 101-102).

95 Na marginesie można dodać, że zdaniem Hałasa do „totalitarnych ustrojów zalicza się przede wszystkim ustrój faszystowski i komunistyczny". Uwaga ta jest tak niezrozumiała, gdyż autor ten przywołał jednocześnie in extenso przepis art. 13 Konstytucji, w którym — jak pamiętamy - wyodrębniono trzy systemy totalitarne: faszystowski, nazistowski i komunistyczny. Możliwe, że Hałas uznaje nazizm za odmianę faszyzmu. Przypomnijmy przy tej okazji, że niebezpieczeństwo związane z łączeniem art. 256 k.k. z art. 13 Konstytucji polega na tym, że zakres kryminalizacji ogranicza się w ten sposób do pewnych historycznych zjawisk i gubi faktyczne zagrożenia totalitarne dla wolności człowieka, o których wspominał Sartori w swej koncepcji totalitaryzmu. Zob. T. Scheffler, Przestępstwo art. 256 k.k. Część ogólna, s. 102-103.

96 R.A. Stefański, Kodeks karny z orzecznictwem i piśmiennictwem (za lata 1998-2003), Toruń 2004; idem, Prawo karne materialne. Część szczególna, Warszawa 2009. W pierwszej z przywołanych pozycji znalazła się jedynie treść uchwały SN z dnia 28 marca 2002 roku; ponieważ tekst ten nie zawiera dodatkowych opinii Stefańskiego, nie będzie przedmiotem osobnego omówienia. 
że ochrona ustroju demokratycznego wymaga gwarancji prawnych, w tym prawa karnego. Uznał również, że zasadniczo art. 256 k.k. typizował jedno przestępstwo „publicznego propagowania faszystowskiego lub innego totalitarnego ustroju państwa, jak też nawoływania do nienawiści na tle różnic narodowościowych, etnicznych, rasowych, wyznaniowych albo ze względu na bezwyznaniowość", gdyż ,przedmiotem ochrony art. 256 KK są prawidłowe funkcjonowanie demokratycznego państwa prawa (główny przedmiot ochrony) oraz wolność grup narodowych, rasowych, wyznaniowych lub bezwyznaniowych (dodatkowy przedmiot ochrony) [wyr. w oryginale - T.S.]" 97.

Jak wyjaśniliśmy to już w dwóch poprzednich artykułach cyklu, art. 256 k.k. penalizuje dwa odrębne czyny i łączenie ich w jedno przestępstwo jest nieprawidłowe. Na marginesie można dodatkowo przypomnieć, że współczesna nauka odstępuje od uznawania, że istnieją odrębne rasy ludzkie ${ }^{98}$, co powoduje, iż pisanie o wolności ,grup rasowych” jako przedmiocie ochrony staje się mocno problematyczne.

W kwestii rozumienia pojęcia „propagowanie” Stefański zasadniczo powtórzył swoje wcześniej omówione uwagi w pełni aprobujące stanowisko Sądu Najwyższego w tym zakresie ${ }^{99}$. Wzbogacił je jedynie o opinię, że działanie to oznacza „rozpowszechnianie według własnej oceny dobrych i korzystnych myśli, idei, zachowań, zachęcanie do przyjmowania, wpływanie na wzrost popularności" 100 . Utrwalił $\mathrm{w}$ ten sposób stanowisko łączące propagowanie $\mathrm{z}$ pochwalaniem (idei dobrych i korzystnych według własnej oceny), ale też przychylił się pośrednio do przyjęcia, że propagowanie może odbywać się w zamiarze ewentualnym („wpływanie na popularność" może być skutkiem ubocznym).

Ciekawy fragment pracy Stefańskiego dotyczy próby przybliżenia znaczenia pojęć „ustrój faszystowski”, „faszyzm” oraz „ustrój totalitarny”. O ile w wypadku faszyzmu autor ograniczył się praktycznie wyłącznie do przypomnienia źródła nazwy (wiązka, związek, rózgi liktorskie), to w odniesieniu do kwestii ustroju faszystowskiego wypowiedział kilka ciekawych intuicji. Uznał bowiem, że jest to „ustrój państwa oparty na doktrynie faszystowskiej, sprzeciwiającej się demokracji parlamentarnej oraz głoszącej kult państwa (statolatrię), silne przywództwo i solidaryzm społeczny" 101 . Zwraca tu uwagę trafne odwołanie się do idei statolatrii, która faktycznie i na poły oficjalnie została wyartykułowana tylko

97 R. Stefański, Prawo karne..., s. 442.

98 Szerzej por. R. Tyrała, O jeden takson za dużo. Rasa jako kategoria społecznie problematyczna, Warszawa 2005.

99 Jako ciekawostkę można tu wskazać, że Stefański, cytując uchwałę SN z 28 marca 2002 roku zarówno w pracy z 2004 roku, jak i w podręczniku z 2009 roku, popełnił ten sam błąd polegający na pominięciu słowa „prezentowaniu” — „Propagowanie [...] oznacza każde zachowanie polegające na publicznym, w zamiarze [...]" — idem, Kodeks karny..., s. 349; idem, Prawo karne..., s. 442.

100 R. Stefański, Prawo karne ..., s . 443.

101 Ibidem. 
w państwie faszystowskim. Niemniej jednak warto też zauważyć, po pierwsze, że statolatria nie została nigdy przekształcona $\mathrm{w}$ element konstytutywny realnego ustroju Włoch faszystowskich (pozostała postulatem, choć wpływającym na prawodawstwo, na przykład na rozbudowane przepisy karne chroniące państwo), a po drugie, że pozostałe elementy opisujące ustrój faszystowski (szczególnie solidaryzm społeczny) można odnaleźć w wielu systemach autorytarnych (na przykład w Polsce po zamachu majowym). Stefański dodał również, że w państwie faszystowskim ,funkcje ustawodawcze i wykonawcze przejmuje wódz (we Włoszech Duce, polityk Benito Mussolini [...]), który łączył stanowisko prezydenta, premiera, zwierzchnika sił zbrojnych oraz głównodowodzącego"102. Jak pamiętamy, charakterystyka nie oddaje prawidłowo specyfiki włoskiej, w której władza należała też do króla oraz Wielkiej Rady Faszystowskiej, wobec czego monolityczne obrazowanie władzy w państwie faszystowskim jest niezgodne z faktami.

Dotychczasowe rozważania pokazywały stan egzegezy art. 256 k.k. przed zmianą konstrukcji tego przepisu, jaka nastąpiła w 2009 roku. W następnym, ostatnim artykule cyklu ukazane zostanie, czy — i jeżeli tak, to w jakim stopniu — nowelizacja brzmienia tego artykułu wpłynęła na jego interpretację w środowiskach naukowych oraz w sądownictwie.

\section{Bibliografia}

Arendt H., Totalitarian ideology, [w:] Totalitarianism: Temporary Madness or Permanent Danger?, red. T. Mason, Boston 1967, s. 42-51.

Arystoteles, Etyka nikomachejska, [w:] Arystoteles, Dzieła wszystkie, przeł. D. Gromska, t. 5, Warszawa 2002 s. 77-383.

Arystoteles, Polityka, Warszawa 2012.

Bartoszewicz M., Wokót problematyki art. 13 Konstytucji RP, „Państwo i Prawo” 2005, nr 4, s. 36-48.

Bień-Kacała A., Jackiewicz A., Militant democracy — demokracja, która sama się broni (?), „Państwo i Prawo" 2017, nr 8, s. 25-41.

Bosiacki A., Utopia. Wtadza. Prawo. Doktryna i koncepcje prawne „,bolszewickiej” Rosji 19171921, Warszawa 1999.

Bracher K.D., Die deutsche Diktaturoku Entstehung, Struktur, Folgen des Nationalsozialismus, Köln 1993.

Brożek B., Granice interpretacji, Kraków 2014.

Chojnicka K., Olszewski H., Historia doktryn politycznych i prawnych. Podręcznik akademicki, Poznań 2004.

Ćwiąkalski Z., Komentarz do art. 256, [w:] Kodeks karny. Część szczególna. Komentarz do art. 117-277 Kodeksu karnego, red. A. Zoll, t. 2, Kraków 1999, s. 914-916.

Dąbrówka A., Geller E., Turczyn R., Stownik synonimów, Warszawa 1993.

Eliasz K., Obowiazywanie prawa w ujęciu skandynawskiego realizmu prawnego, [w:] Naturalizm prawniczy. Stanowiska, red. B. Brożek, K. Eliasz, Ł. Kurek, J. Stelmach, Warszawa 2015, s. $187-200$.

Feuerbach P.J.A., Lehrbuch des gemeinen in Deutschland gültigen peinlichen Rechts, Giessen 1812.

102 Ibidem.

Studia nad Autorytaryzmem i Totalitaryzmem 41, nr 1, 2019

(C) for this edition by CNS 
Flemming M., Kutzmann W., Przestępstwa przeciwko porządkowi publicznemu. Rozdziat XXXII Kodeksu karnego. Komentarz, Warszawa 1999.

Foro Ph., Włochy faszystowskie, Kraków 2008.

Forti S., Il totalitarismo, Roma-Bari 2001.

Frankiewicz A., Regulacja wolności wypowiedzi w polskim porządku prawnym, [w:] Prawa i wolności obywatelskie w Konstytucji RP, red. B. Banaszak, A. Preisner, Warszawa 2002, s. 361-398.

Friedrich C.J., Brzezinski Z., Merkmale der totalitären Diktatur, [w:] Nationalsozialistische Diktatur 1933-1945. Eine Bilanz, red. K.D. Bracher, M. Funke, H.A. Jacobsen, Bonn 1983, s. $225-$ 236.

Gajda J., Sofiści, Warszawa 1989.

Gardocki L., Granice wolności słowa w projekcie kodeksu karnego, „Palestra” 1993, nr 12, s. 103106.

Gardocki L., Prawo karne, Warszawa 2001.

Garlicki L., Polskie prawo konstytucyjne. Zarys wyktadu, Warszawa 2004.

Giezek J., Typizacja przestepstw oraz jej elementy, [w:] M. Bojarski, J. Giezek, Z. Sienkiewicz, Prawo karne materialne. Część ogólna i szczególna, Warszawa 2007, s. 91-129.

Giezek J., Wina oraz okoliczności ja wyłaczajace, [w:] M. Bojarski, J. Giezek, Z. Sienkiewicz, Prawo karne materialne. Część ogólna i szczególna, Warszawa 2007, s. 164-196.

Gorazda M., Uźródet amerykańskiego realizmu prawnego, [w:] Naturalizm prawniczy. Stanowiska, red. B. Brożek et al., Warszawa 2015, s. 165-186.

Góral R., Kodeks karny. Praktyczny komentarz, Warszawa 2000.

Górniok O., Komentarz do art. 256, [w:] O. Górniok, S. Hoc, S.M. Przyjemski, Kodeks karny. Komentarz, t. 3, Gdańsk 1999, s. 300-302.

Grodziński E., Językoznawcy i logicy o synonimach i synonimice, Wrocław 1985.

Haack S., O pragmatyzmie prawnym: dokad wiedzie nas Ścieżka prawa?, [w:] Naturalizm prawniczy. Stanowiska, red. B. Brożek, K. Eliasz, Ł. Kurek, J. Stelmach, Warszawa 2015, s. 131-164.

Hałas R., Komentarz do art. 256 k.k., [w:] Prawo karne, red. A. Grześkowiak, Warszawa 2007, s. 348-349.

Hoc S., Glosa do uchwały SN z dnia 28 marca 2002 roku, „Orzecznictwo Sądów Polskich” 46, 2002, nr 12, K 164, s. 648-650.

Hoc S., O przestępstwach z art. 256 K.K., „Problemy Prawa Karnego” 2003, nr 22, s. 53-60.

Hoc S., Przestepstwo propagandy antypaństwowej w polskim prawie karnym, Wrocław 1981.

Jakubiec M., Tu-Tu Alfa Rossa a tezy skandynawskiego realizmu prawnego, [w:] Naturalizm prawniczy. Stanowiska, red. B. Brożek, K. Eliasz, Ł. Kurek, J. Stelmach, Warszawa 2015, s. 201-220.

Jurewicz J., Kryterium podobieństwa przestępstw w ujęciu kodeksu karnego, „Państwo i Prawo” 2008, nr 11, s. 77-83.

Kalitowski M., Komentarz do art. 256, [w:] Kodeks karny. Komentarz, red. O. Górniok, Warszawa 2004, s. 733-734.

Klarman A., Argumentacja perswazyjna jako technika spoleczna w polityce prawa, „Prakseologia” 2004, nr 144, s. 199-219.

Kodeks karny. Część ogólna, t. 1, cz. 1. Komentarz do art. 1-52, red. W. Wróbel, A. Zoll, wyd. 5, LEX 2016.

Kolb E., Die Maschinerie des Terrors. Zum Funktionieren des Unterdrückungs- und Verfolgungsapparates im NS-System, [w:] Nationalsozialistische Diktatur 1933-1945. Eine Bilanz, red. K.D. Bracher, M. Funke, H.A. Jacobsen, Bonn 1983, s. 270-284.

Kołakowski L., Główne nurty marksizmu. Powstanie - rozwój — rozkład, Londyn 1988.

Lexicography: Critical Concept, red. R.R.K. Hartmann, t. 1. Dictionaries, Compilers, Critics and Users, London-New York 2003.

Lyons J., Wstęp do językoznawstwa, Warszawa 1975.

Studia nad Autorytaryzmem i Totalitaryzmem 41, nr 1, 2019

(C) for this edition by CNS 
Maciejewski M., Od piwiarnianego klubu do organizacji wywrotowej. Nazizm w latach 1919-1924, Torun 2005.

Maciejewski M., Scheffler T., O doktrynologii: rozważania dotyczace przedmiotu oraz metody doktryn politycznych i prawnych, [w:] Myślenie o polityce i prawie. Przedmiot. Metoda. Praktyka, red. I. Barwicka-Tylek, A. Czarnecka, M. Jaskólski, J. Malczewski, Warszawa 2015, s. 263-297.

Mały stownik języka polskiego, red. S. Skorupka, H. Auderska, Z. Łempicka, Warszawa 1968.

Marek A., Prawo karne, Warszawa 2001.

Markowski A., Słowo wstepne, [w:] Nowy słownik poprawnej polszczyzny, red. A. Markowski, Warszawa 1999, s. IX-XI.

Mill J.S., O wolności, [w:] idem, Utylitaryzm. O wolności, Warszawa 2005, s. 93-227.

Morawski L., Główne problemy współczesnej filozofii prawa. Prawo w toku przemian, Warszawa 2003.

Nowicki M.A., Europejska Konwencja Praw Człowieka. Wybór orzecznictwa, Warszawa 1999.

Nowicki M.A., Kamienie milowe. Orzecznictwo Europejskiego Trybunału Praw Człowieka, Warszawa 1996.

Nowicki M.A., Wokót Konwencji Europejskiej. Krótki komentarz do Europejskiej Konwencji Praw Człowieka, Kraków 2000.

Oniszczuk J., Konstytucja Rzeczypospolitej Polskiej w orzecznictwie Trybunatu Konstytucyjnego, Kraków 2000.

Pankowski R., Kornak M., Poland, [w:] Racist Extremism in Central and Eastern Europe, red. C. Mudd, London-New York 2005, s. 145-170.

Perelman Ch., Logika prawnicza. Nowa retoryka, Warszawa 1984.

Platon, Państwo, Kęty 1999.

Popper K.R., Przedmowa do czytelnika polskiego, [w:] idem, Spoleczeństwo otwarte i jego wrogowie, t. 1. Urok Platona, Warszawa 1993, s. 11-13.

Popper K.R., Społeczeństwo otwarte i jego wrogowie, t. 1. Urok Platona, Warszawa 1993.

Praktyczny słownik współczesnej polszczyzny, red. H. Zgółkowa, t. 29, Poznań 2000.

Praktyczny słownik współczesnej polszczyzny, red. H. Zgółkowa, t. 32, Poznań 2001.

Proto-Indo-European Etymological Dictionary: A Revised Edition of Julius Pokorny's Indogermanisches Etymologisches Wörterbuch, https://marciorenato.wordpress.com/linguistica-indo-europeia/ (dostęp: 22.02.2019).

Reale G., Historia filozofii starożytnej, t. 1. Od początków do Sokratesa, Lublin 2000.

Ryszka F., Państwo stanu wyjątkowego. Rzecz o systemie państwa i prawa Trzeciej Rzeszy, Wrocław 1985.

Safjan M., Wyzwania dla państwa prawa, Warszawa-Kraków 2007.

Sakowicz A., Glosa do uchwaty SN z 28 marca 2002 roku, „Palestra” 2003, nr 3-4, s. 238-243.

Sartori G., Teoria demokracji, Warszawa 1994.

Scheffler T., Ekstremizm polityczny: nieudana próba delegalizacji Narodowodemokratycznej Partii Niemiec (NPD) w latach 2001-2003 i jej znaczenie dla polskiego porzadku prawnego, „Studia nad Autorytaryzmem i Totalitaryzmem" 37, 2015, nr 3, s. 89-103.

Scheffler T., Przestęstwo publicznego propagowania faszystowskiego lub innego totalitarnego ustroju państwa (art. 256 k.k.). Analiza doktrynologiczna wybranych wypowiedzi piśmiennictwa i judykatury. Część ogólna, „Studia nad Autorytaryzmem i Totalitaryzmem” 34, 2012, nr 3, s. 97-117.

Scheffler T., Przestepstwo publicznego propagowania faszystowskiego lub innego totalitarnego ustroju państwa (art. 256 k.k.). Analiza doktrynologiczna wybranych wypowiedzi piśmiennictwa i judykatury. Część szczególna I, „Studia nad Autorytaryzmem i Totalitaryzmem” 40, 2018, nr 4, s. 145-159.

Studia nad Autorytaryzmem i Totalitaryzmem 41, nr 1, 2019

(C) for this edition by CNS 
Scheffler T., Zasada nullum crimen sine lege $w$ kontekście przestępstw stypizowanych $w$ art. $256 \xi 1$ k.k., „Opolskie Studia Administracyjno-Prawne” 16, 2018, nr 4 [w druku].

Skibiński A., Gregory Bateson i kontekstowa teoria komunikacji. Różnica, która czyni różnice, i wzorzec, który lączy, [w:] Komunikologia. Teoria i praktyka komunikacji, red. E. Kulczycki, M. Wendland, Poznań 2012, s. 69-88.

Stownik języka polskiego PWN, red. W. Doroszewski, t. 8, Warszawa 1966.

Stanek J., Rosyjski realizm prawny. Psychologiczna koncepcja prawa - powstanie i rozwój, [w:] Naturalizm prawniczy. Stanowiska, red. B. Brożek, K. Eliasz, Ł. Kurek, J. Stelmach, Warszawa 2015, s. 221-232.

Stefański R.A., Kodeks karny z orzecznictwem i piśmiennictwem (za lata 1998-2003), Toruń 2004.

Stefański R.A., Prawo karne materialne. Część szczególna, Warszawa 2009.

Stefański R.A., Przegląd uchwat Izby Karnej Sadu Najwyższego w zakresie prawa karnego materialnego, prawa karnego wykonawczego, prawa karnego skarbowego i prawa wykroczeń za 2002 roku, „Wojskowy Przegląd Wojskowy” 2003, nr 1 (225), s. 97-99.

Stelmach J., Sarkowicz R., Filozofia prawa XIX i XX wieku, Kraków 1998.

Synonim, [hasło w:] Nowy stownik poprawnej polszczyzny, red. A. Markowski, Warszawa 1999, s. 997.

Szabelska A., Claude Lévi-Strauss i strukturalna analiza mitu a przyczynek do badań kognitywnych, „Via Mentis” 2012, nr 1, s. 99-108.

Szulczewski M., Propaganda polityczna. Pojęcia - funkcje - problemy, Warszawa 1971.

Taureck B.H.F., Die Sophisten. Eine Einführung, Berlin 1994.

Tokarz M., Argumentacja i perswazja, „Filozofia Nauki” 10, 2002, nr 3-4, s. 5-34.

Tyrała R., O jeden takson za dużo. Rasa jako kategoria spolecznie problematyczna, Warszawa 2005. Ullmann S., The Principles of Semantics: A Linguistic Approach to Meaning, Oxford 1957.

Urbańczyk M., Liberalna doktryna wolności stowa a swoboda wypowiedzi historycznej, Poznań 2009.

Warylewski J., Kierunki i szkoły w nauce prawa karnego, [w:] System prawa karnego, t. 1. Zagadnienia ogólne, red. A. Marek, Warszawa 2010, s. 49-98.

Werth N., Państwo przeciw spoleczeństwu. Przemoc, represje i terror w Związku Sowieckim, [w:] S. Courtois, N. Werth, J.L. Panné, A. Paczkowski, K. Bartosek, J.L. Margolin, Czarna księga komunizmu. Zbrodnie, terror, prześladowania, Warszawa [b.r.w.], s. 57-253.

Wojciechowski J., Kodeks karny. Komentarz. Orzecznictwo, Warszawa 2000.

Wronkowska S., Ziembiński Z., Zarys teorii prawa, Poznań 2001.

Wróblewski J., Rozumienie prawa i jego wykładnia, Wrocław 1990.

Zabłocki S., Przegląd orzecznictwa Sądu Najwyższego — Izba Karna, „Palestra” 2002, nr 5-6, s. $145-146$.

Zieliński M., Wykładnia prawa. Zasady - reguly - wskazówki, Warszawa 2017.

Zmierczak M., Spory o istote faszyzmu. Dzieje i krytyka, Poznań 1988.

Žižek S., Postowie. Wybór Lenina, [w:] idem, Rewolucja u bram. Pisma wybrane z roku 1917 W.I. Lenina, Kraków 2007, s. 303-628.

\section{THE CRIME OF PUBLIC PROPAGATION OF A FASCIST OR OTHER TOTALITARIAN GOVERNMENTAL SYSTEM (ARTICLE 256 OF THE PENAL CODE): A DOCTRINOLOGICAL ANALYSIS OF SELECTED SCHOLARLY WRITINGS AND JUDICATURE. DETAILED PART II}

\section{Summary}

The paper presents interpretations of the content of art. 256 of the Polish Penal Code of 1997 (The crime of public propagation of a fascist or other totalitarian governmental system), which were developed before 2009. The most difficult problem for commentators, much like authors, about 
whom we have deliberated earlier, was to understand the complexity of the phenomenon of totalitarianism and the consequences resulting from accepting one of the competing concepts of totalitarianism. Similarly, interpretational problems led to misunderstandings of the concept of fascism and the governmental system. As a result, individual authors incorrectly found resemblance between the regulations contained in the Penal Code of 1969 and the regulation contained in art. 256 from 1997. In this paper we prove that the Polish Supreme Court also had the same problem with the interpretation of the content of art. 256.

Keywords: totalitarianism, fascism, penal code.

Tomasz Scheffler

tomasz.scheffler@uwr.edu.pl 